\title{
Drivers and effects of labour market reforms: Evidence from a novel policy compendium
}

\author{
Dragos Adascalitei ${ }^{1}$ and Clemente Pignatti Morano ${ }^{2^{*}}$
}

\author{
*Correspondence: pignatti@ilo.org \\ ${ }^{2}$ Research Department, International \\ Labour Organization, Route des \\ Morillons 4, Geneva CH1211, \\ Switzerland \\ Full list of author information is \\ available at the end of the article
}

\begin{abstract}
The paper analyses the determinants and short-term effects of labour market reforms, using information from a novel policy compendium that covers 110 developed and developing economies between 2008 and 2014. We find that the approval of reforms is positively associated with the unemployment rate, the simultaneous implementation of fiscal consolidation measures and the presence of a fixed exchange rate regime. Differences in the results are explored by looking at the direction of reforms (i.e. increasing or decreasing legislation), temporal horizon (i.e. temporary or permanent measures) and coverage (i.e. complete or two-tier reforms); while also analysing separately reforms' determinants across domains of labour legislation (e.g. permanent contracts, collective dismissals). Finally, we find that deregulatory labour market reforms tend to increase the unemployment rate in the short run when they are approved during contractionary periods - while they have a non-significant effect when approved during periods of economic stability or expansion.
\end{abstract}

JEL Classification: J20, J52, J38, J48, J58, K31

Keywords: Labour market reforms, Employment protection legislation, Unemployment, Developed economies, Developing economies

\section{Introduction}

Reforms of labour legislation have been amongst the most widely spread policy interventions used by governments in recent years in order to address the negative effects of the global financial and economic crisis. In developed economies, labour market legislation reforms have been perceived as useful instruments to sustain employment levels in times of rising unemployment rates and limited public resources (OECD 2012). In developing countries, the attention towards labour market legislation has mostly concerned the need to protect workers against shocks in labour demand resulting from fluctuations in international trade (ILO 2015a). In both cases, policy interventions have differed with respect to their (i) motivation (e.g. enhance competitiveness or kick-start job creation); (ii) direction (e.g. increasing or decreasing protection); and (iii) area of intervention (e.g. permanent or temporary workers, collective bargaining). This variation raises questions about the determinants of labour market reforms as well as about the effectiveness of these reforms in improving labour market outcomes. In an effort to better understand these developments, we build a novel compendium of

(c) 2016 The Author(s). Open Access This article is distributed under the terms of the Creative Commons Attribution 4.0 International License (http://creativecommons.org/licenses/by/4.0/), which permits unrestricted use, distribution, and reproduction in any medium, provided you give appropriate credit to the original author(s) and the source, provide a link to the Creative Commons license, and indicate if changes were made. 
labour market reforms that covers 110 advanced and developing economies for the period between 2008 and 2014. To our knowledge, this represents one of the most comprehensive attempts to map changes in labour market legislation during the crisis-both in terms of countries covered as well as areas of employment legislation. A descriptive analysis based on the data in our compendium shows that reform intensity has increased during the first phase of the recession, reaching a peak in 2012. Between 2012 and 2014 the average number of reforms passed annually decreased, matching levels that characterized the pre-crisis period. Moreover, the majority of reforms have decreased existing levels of regulation-although large disparities are registered across geographical regions and policy subdomains. Reforms of permanent contracts have been at the centre of the attention of policymakers in developed economies, while governments in developing economies have primarily reformed collective bargaining institutions. Finally, the majority of reforms have been of permanent (rather than temporary) nature and they have targeted the entire eligible population (rather than specific subgroups).

Drawing on our compendium of labour market reforms, the purpose of the paper is twofold. First, it seeks to explain determinants of reforms' approval. The results of the analysis show that high and increasing unemployment rates have positively affected the probability of adopting labour market reforms. At the same time, the approval of reforms is positively associated with the simultaneous implementation of fiscal consolidation measures as well as the presence of a fixed exchange rate regime. These results partially confirm the findings from earlier studies (Turrini et al. 2015; Duval and Elmeskov 2006; Høj et al. 2006), while expanding their geographical coverage. The paper then examines the determinants of labour market reforms across policy directions (i.e. increasing or decreasing legislation), temporal horizon (i.e. temporary or permanent measure) and coverage (i.e. complete or two-tier intervention). Furthermore, it also examines the different labour market subdomains where reforms have been implemented. Our results show that determinants of labour market reforms approved between 2008 and 2014 do indeed differ across these dimensions, thus providing new insights to the existing literature. Finally, we examine the short-term effects of labour market reforms on unemployment rates. In the baseline specification, we find no effects of either a reduction or an increase in labour market regulation on changes in unemployment. However, when analysing the effects of reforms at different points of the business cycle, the results reveal that deregulatory labour market reforms increase the unemployment rate in the short run when they are approved during crises-while not having a statistically significant effect if they are implemented during periods of economic stability or expansion. These results are in line with the previous literature which argues that structural reforms might have unintended consequences when implemented during economic crises (Cacciatore et al. 2012; Bouis et al. 2012).

The remainder of the paper is organized as follows. Section 2 describes the methodology used to compile the policy compendium and presents the main reform trends derived from it. Section 3 discusses the empirical results looking at the determinants (Section 3.1) and short-term effects (Section 3.2) of labour market reforms. Section 4 summarizes our findings and concludes.

\section{Changes to labour market regulation around the world (2008-14)}

The paper uses information on labour market reforms collected in a novel policy compendium that covers 110 developed and developing economies between 2008 and 2014 . 
The methodology used to compile and code the data follows previous work in this field (e.g. Turrini et al. 2015), while being adapted to the wider geographical coverage (i.e. developed and developing economies) and the narrower area of research interest (i.e. employment protection). In particular, the main sources of information are represented by the ILO employment protection legislation database (EPLex) and the ILO database of national labour, social security and related human rights legislation (NATLEX). These are the two most comprehensive inventories of labour legislation with a global coverage, presenting detailed and comparable information on the state of labour legislation in both developed and developing countries. In order to ensure that our coding of reforms is consistent with the data used in previous studies (Turrini et al. 2015; Boeri 2011), the information collected from the ILO databases is complemented and crosschecked with the data available in the EU Commission database on labour market reforms (LABREF) and the social reforms database of the Fondazione Rodolfo Debenedetti (fRDB) and IZA. Additionally, in order to limit the risk of missing information (especially for developing countries, for which ILO databases might be updated less regularly), we have complemented the data sources discussed above with information coming from official national and international reports (ILO 2012). ${ }^{1}$ For every policy intervention that is identified through this mapping exercise, the compendium provides a brief description of the content of the legislative change, the year of its approval and implementation (if they differ) and the labour legislation policy subdomain to which the change applies. In particular, the compendium distinguishes between changes in the legislation of (i) permanent employment contracts; (ii) temporary employment contracts; (iii) other forms of employment (e.g. teleworkers, dependent self-employees); (iv) collective bargaining institutions; (v) collective dismissals; and (vi) working hours. This classification represents an expansion compared to the traditional understanding of employment protection legislation (EPL) (i.e. permanent contracts, temporary contracts and collective dismissals), which is motivated by the attempt to include policy changes that are more likely to occur during periods of economic downturns (e.g. working hours) as well as to better account for reform efforts that cover emerging forms of work (ILO 2015b). However, for parsimony, we cannot include all areas of labour legislation and important subdomains (e.g. anti-discrimination) remain uncovered. If different changes to labour market regulation were passed within a single reform package (e.g. changes in both notice period and severance payments for permanent contracts), these interventions are coded separately. Furthermore, since legislatives do not usually pass single-issue policy reforms, but rather complex packages that impact various subdomains of labour legislation, these packages are broken down by subdomain as well as by the number of changes passed in a particular subdomain. For example, the 2012 Spanish labour market reform (Law 3/2012) introduced substantial changes across different labour market areas (e.g. permanent contracts and collective bargaining). In order to correctly code the reform, the overall reform package has been first differentiated by policy subdomain and then within each subdomain, every change has been identified separately. As a result, the compendium records a total number of 18 changes in the legislation that are connected to the Spanish reform of 2012. As such, the term "reform" in the present study should read as indicating a single change in the legislation-rather than a full-fledged reform. 
Despite the fact that this coding procedure aims at minimizing the issues related to the variation in the importance of reforms, it is still limited in addressing some of the structural shortcomings connected with the use of count data. In particular, higher counts for a particular country or policy subdomain do not necessarily reflect that more extensive or effective policies are being adopted by governments (Turrini et al. 2015). For instance, a gradualist reform approach would be incorrectly interpreted as a sign of policy activism compared to an abrupt single change to the legislation. Similarly, policy reversals could inflate the number of interventions registered in the compendium. Different methods have been developed in the literature to deal with this problem. For instance, Kucera (2007) obtains indexes of trade union rights' violations after having created a matrix that assigns different weights to each type of violation that is reported in international data sources (e.g. the murder or disappearance of union members is assigned the highest weight). Despite providing an intuitive answer to the problem faced by count data, this methodology strongly relies on arbitrary decisions on the weights to be assigned-which entirely depend on the "author's sense of the severity of each violation" (Teitelbaum 2010). For our purposes, this coding strategy would make this type of exercise extremely difficult due to the variation of labour market reforms present in the compendium as well as their different impacts depending on the country situation in which they intervene. In order to limit the arbitrary nature of this weighting scheme, Teitelbaum (2010) uses item response theory to understand whether the different count items at the centre of the analysis (i.e. in this case, policy reforms) relate to the same latent concept. This methodology provides a more objective basis to construct an overall indicator of interest, but it still would not provide an insight on the different nature and scope of the policy interventions (i.e. treating them equally). For this reason, we follow the methodology proposed by Boeri (2011) and introduce dummies to code labour market reforms along several dimensions. In particular, for each reform, we note (i) the direction of the intervention (i.e. increasing or decreasing legislation); (ii) its temporal horizon (i.e. temporary measure or permanent change in the legislation); and (iii) its coverage/target group as a share of the eligible population (i.e. complete reforms targeting the majority of the eligible population or two-tier reforms applying only to a subgroup). ${ }^{2}$ Although our method seeks to minimize the amount of subjective decisions to be made when coding labour market reforms, some degree of subjectivity remains. For example, reforms that have increased the ability of employers to adjust working hours have been coded in the compendium as deregulatory interventions-although in some circumstances, these were (either directly or indirectly) aimed at avoiding layoffs. However, the benefits connected to the identification of these reforms' characteristics seem to largely outpace the possible shortcomings. Additionally, the coding decisions, although in some cases subjective, are consistently used and can be replicated. In particular, we test the different coding procedures followed in this paper against the measures of accuracy of qualitative indicators proposed by Bollen and Paxton (2000). ${ }^{3}$

Our data shows that a total number of 642 changes to labour regulation have been approved in the 110 countries investigated between 2008 and 2014. ${ }^{4}$ The number of changes approved every year has increased globally in the first phase of the downturn-going from 61 interventions approved in 2008 to a peak of 147 changes in 2012. After 2012 reform intensity has decreased, broadly following trends in 
unemployment rates (see Fig. 1 for details by geographical region). The majority of the interventions ( $55 \%$ ) have brought about a decrease in existing levels of regulation. This stems from a general trend towards deregulation registered in developed

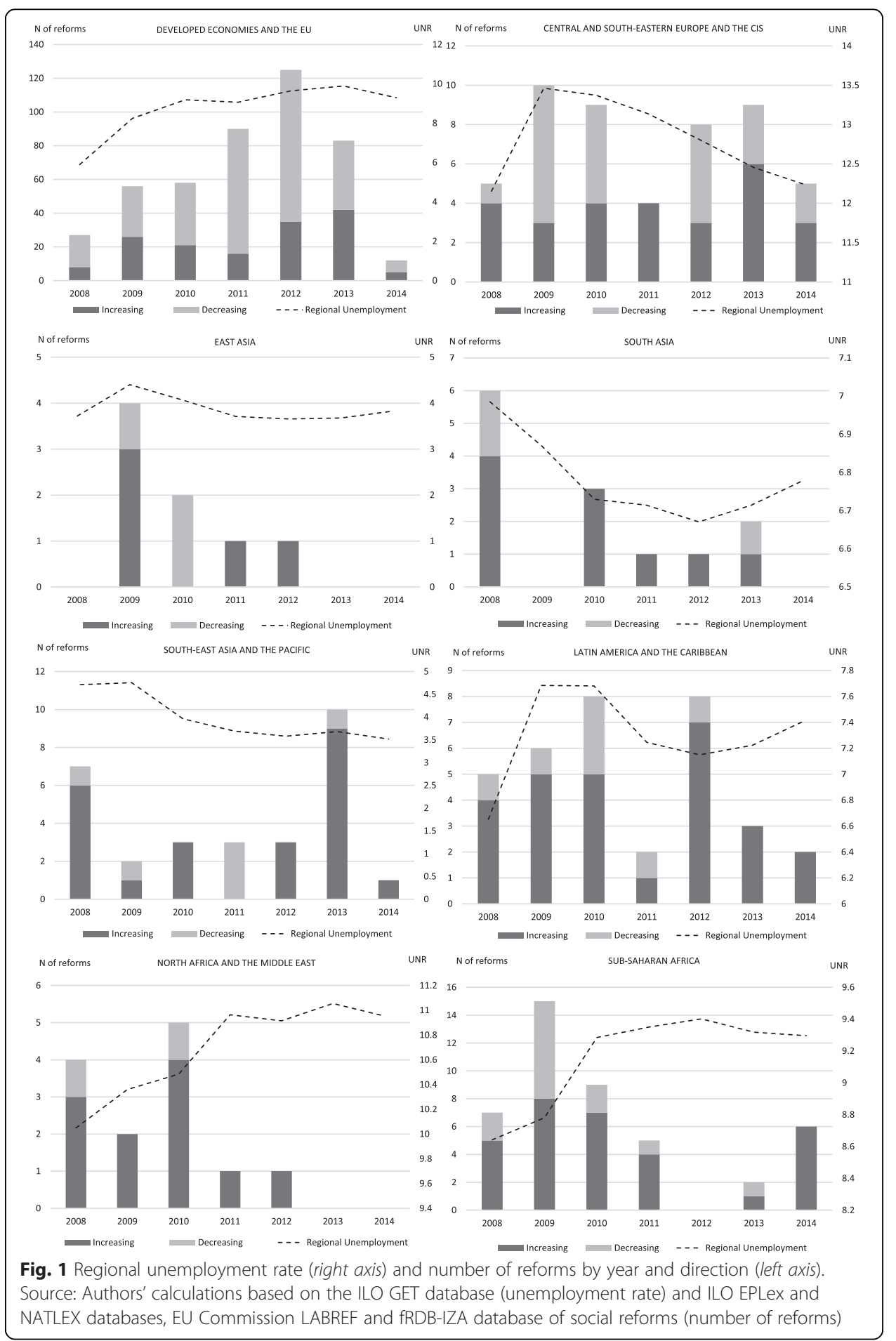


economies-and in particular in EU member states-and a reinforcement of labour legislation in developing countries. In particular, the share of reforms decreasing employment protection has been equal to $66 \%$ of the total in Developed Economies and the EU and $46 \%$ in Central and South-Eastern Europe (CEES) and the Commonwealth of Independent States (CIS)(see Appendix 2 for the list of countries included in each region). As Fig. 2 shows, all other regions have registered lower shares of reforms aimed at decreasing employment protection, ranging between 38 \% (East Asia) and $15 \%$ (North Africa and the Middle East). Furthermore, the majority of the reforms have targeted the entire population, with $69 \%$ of reforms being complete and the remaining $31 \%$ being two-tier reforms. In addition, $92 \%$ of the reforms constitute permanent changes in labour market legislation-which suggests that the crisis led to a long-term shift in labour market regulation around the world. Overall, our descriptive results match the trends described by traditional indicators of EPL, including the OECD indicator and the Cambridge University Centre for Business Research's Labour Regulation Index (CB-LRI) indicator (ILO 2015a).

Looking at labour market reforms by policy subdomain shows that the majority of the reforms have been approved in the areas of permanent contracts $(30 \%)$ and collective bargaining (27\%), followed by reforms on temporary employment contracts (13\%) and working hours (12\%). Relatively less attention has been paid to changes in the legislation of other forms of work and collective dismissals (10 and $8 \%$ of the total, respectively). Overall, large disparities in reform intensity by policy subdomain are registered across regions (see Fig. 3). In particular, Developed Economies and the EU and countries in Central and South-Eastern Europe and the CIS have been mostly concerned with reforms in legislation regarding permanent contracts. Examples include the modification of the legislation over severance payments and notice periods for permanent contracts in Greece, Portugal and Spain as well as the abolition of the obligation of third-party notification for individual layoffs in Belarus,

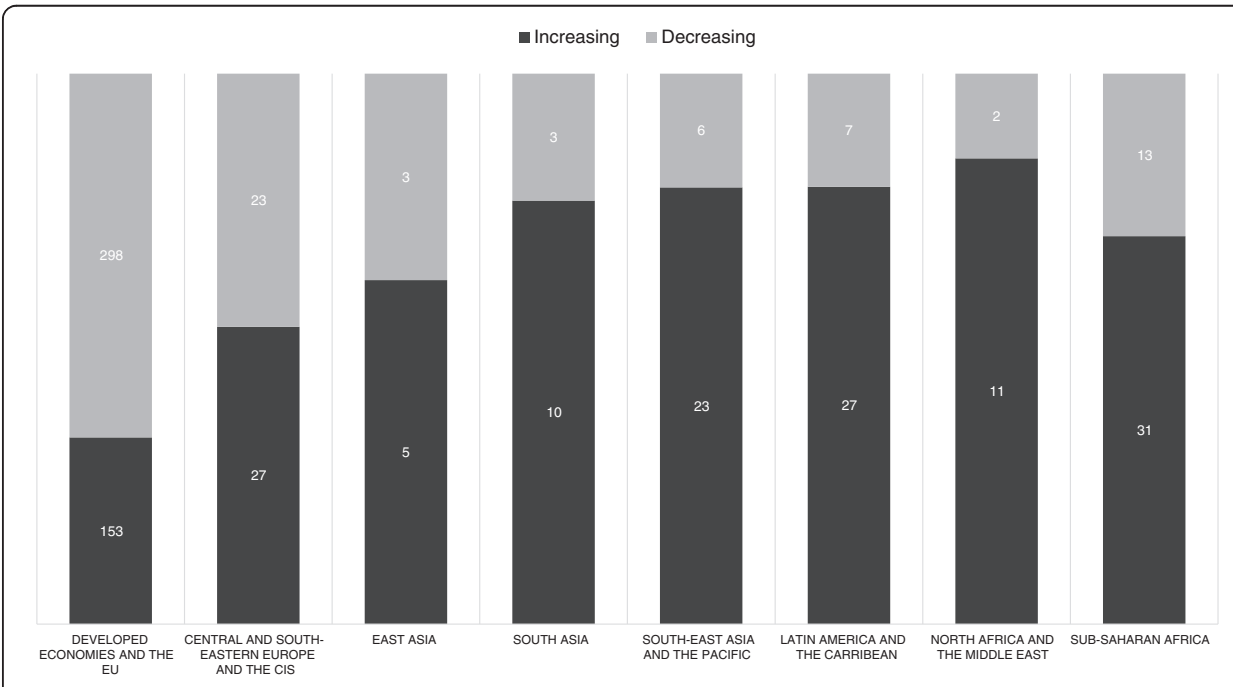

Fig. 2 Number of reforms by direction. Source: Authors' calculations based on the ILO EPLex and NATLEX databases, EU Commission LABREF and fRDB-IZA database of social reforms 


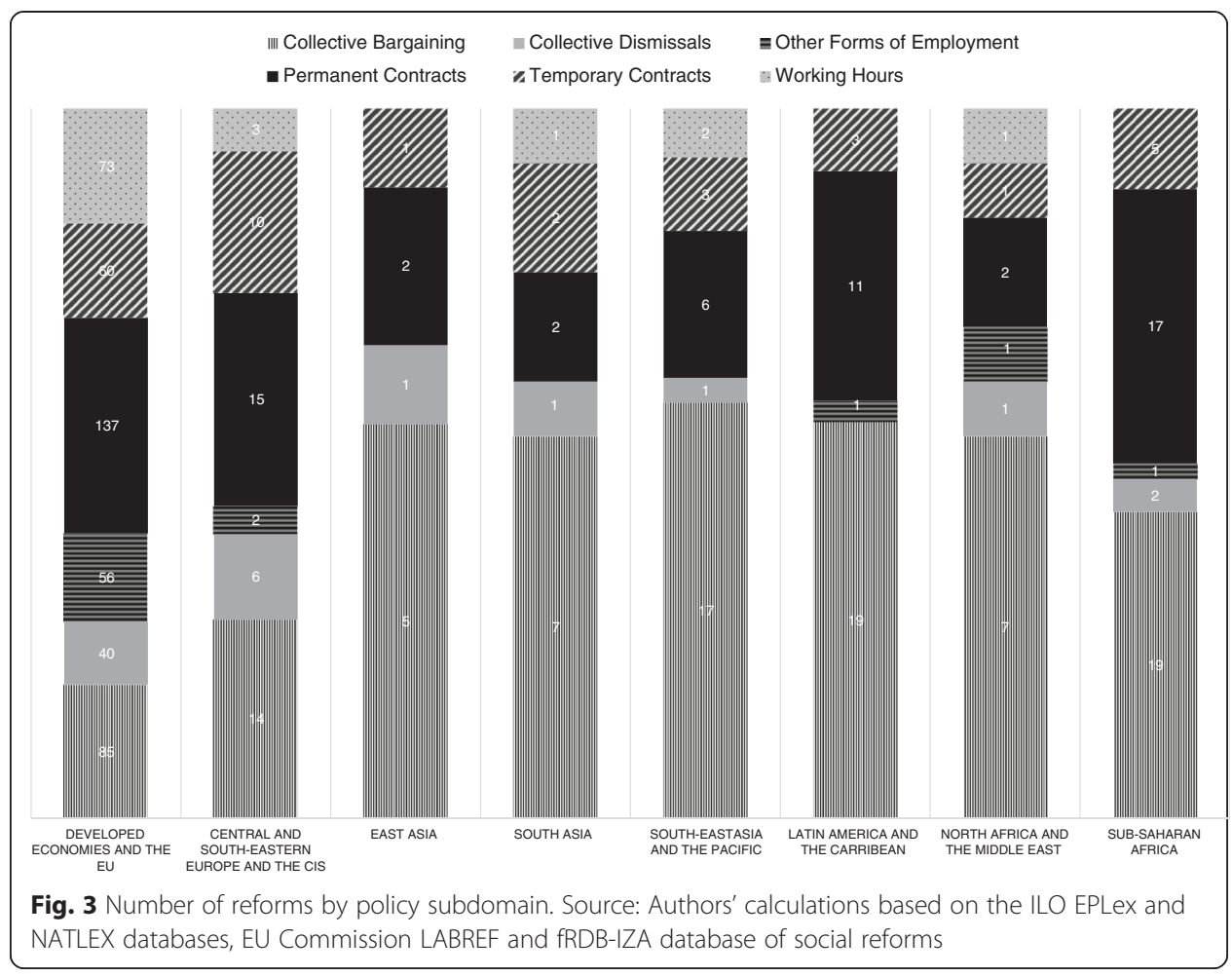

Kyrgyzstan and Montenegro. By comparison, the majority of developing economies have been primarily concerned with reforms in national collective bargaining institutions which in many cases amounted to a process of institution building. Examples include the foundation of tripartite institutions of social dialogue in Angola, Cameroon and Gabon and the reinforcement of trade union rights in different countries in Latin America and the Caribbean including Bolivia and Colombia.

Finally, it is worth noting that the share of reforms decreasing existing levels of regulation has substantially varied across areas of policy intervention, ranging from $74 \%$ of the total for working hours, $65 \%$ for temporary employment contracts, $62 \%$ for collective dismissals, $59 \%$ for permanent contracts, $46 \%$ for collective bargaining and $28 \%$ for other forms of employment. This shows that the deregulatory trend has first concerned crisis-related labour market interventions (i.e. working hours), while reforms aimed at tackling structural issues in the labour market (e.g. other forms of employment) did not show a similar cyclical evolution. Indeed, in many countries (e.g. EU member states), the attention of policymakers has been focused on reinforcing protection for these new forms of work in order to rebalance the stringency of labour regulation vis-à-vis standard forms of work. Such an example is the implementation of the EU Directive on temporary agency workers (Directive 2008/104/EC). This pattern is confirmed by the CB-LRI indicator of labour legislation, which shows that regulation of atypical forms of employment has increased during the recent period in both developed and developing economies (ILO 2015a). In contrast, the legislation concerning collective dismissals or working hours has often been eased especially in cases when the existing regulation was considered to be insufficiently flexible to respond to employers' need of adjusting employment 
levels in crisis conditions. Examples include reductions in the administrative procedures required for conducting collective dismissals in Belarus, Central African Republic and Georgia or simplifications of the requirements needed for employers to modify working hours unilaterally in Greece, Lithuania and Poland (see Fig. 4).

Table 1 summarizes the main descriptive statistics obtained from the policy compendium along the dimensions that have been discussed. It also shows how reform activism has been substantially stronger in developed economies (third column) than developing economies (rest of the columns)-although this is also

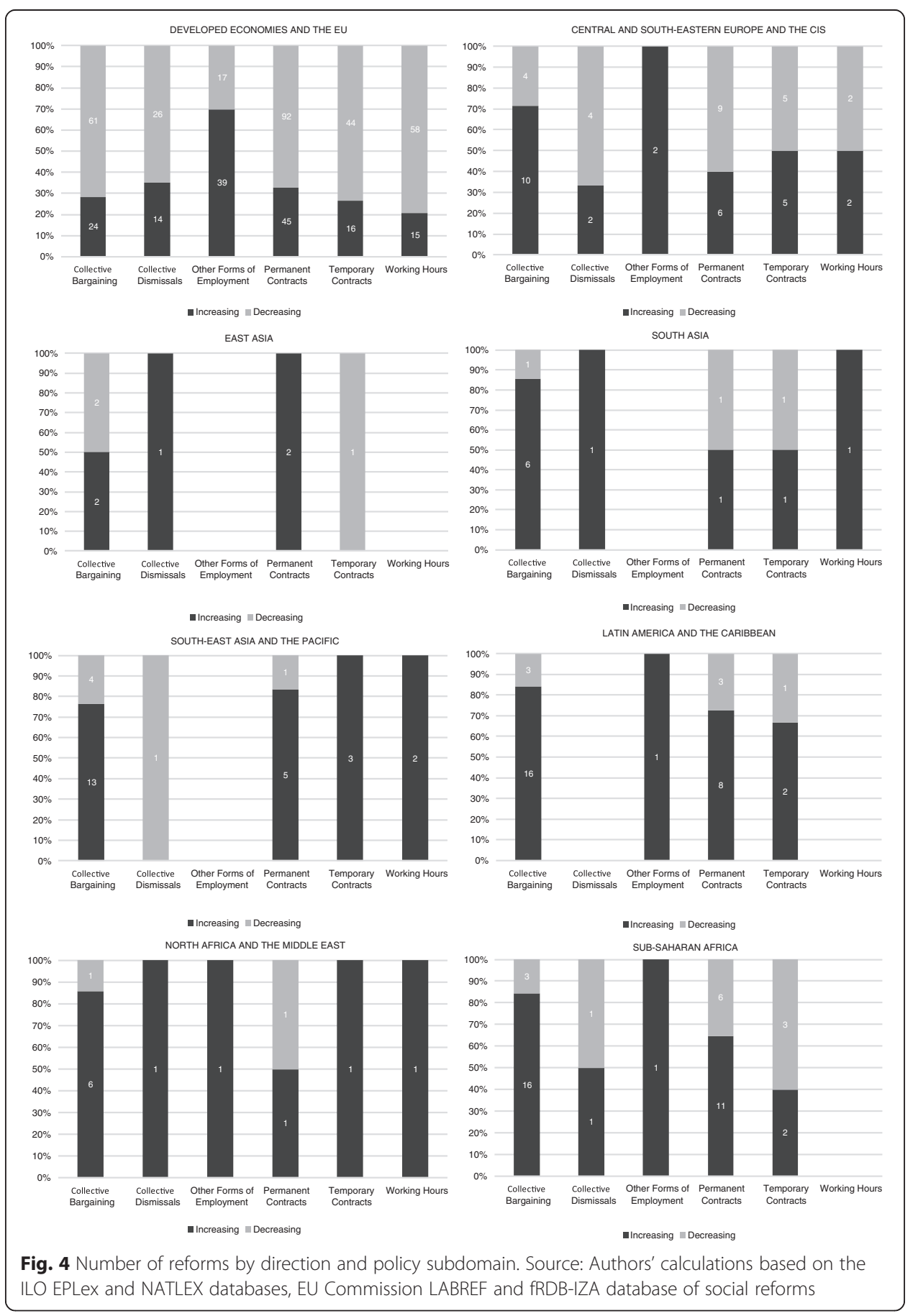


Table 1 Descriptive statistics from the policy compendium

\begin{tabular}{|c|c|c|c|c|c|c|c|c|c|}
\hline & & $\begin{array}{l}\text { Developed Economies } \\
\text { and the EU }\end{array}$ & $\begin{array}{l}\text { Central and South-Eastern } \\
\text { Europe and the CIS }\end{array}$ & East Asia & South Asia & $\begin{array}{l}\text { South-East Asia } \\
\text { and the pacific }\end{array}$ & $\begin{array}{l}\text { Latin America } \\
\text { and the Caribbean }\end{array}$ & $\begin{array}{l}\text { North Africa and } \\
\text { the Middle East }\end{array}$ & Sub-Saharan Africa \\
\hline & Total reforms & 451 & 50 & 8 & 13 & 29 & 34 & 13 & 44 \\
\hline \multirow[t]{2}{*}{ Direction } & Increasing & 153 & 27 & 5 & 10 & 23 & 27 & 11 & 31 \\
\hline & Decreasing & 298 & 23 & 3 & 3 & 6 & 7 & 2 & 13 \\
\hline \multirow[t]{2}{*}{ Coverage } & Complete & 281 & 40 & 6 & 11 & 26 & 32 & 9 & 39 \\
\hline & Two-tier & 170 & 10 & 2 & 2 & 3 & 2 & 4 & 5 \\
\hline \multirow[t]{2}{*}{ Temporal horizon } & Permanent & 408 & 48 & 7 & 13 & 27 & 31 & 11 & 44 \\
\hline & Temporary & 43 & 2 & 1 & 0 & 2 & 3 & 2 & 0 \\
\hline \multirow[t]{6}{*}{ Domain } & $\begin{array}{l}\text { Collective } \\
\text { bargaining }\end{array}$ & 85 & 14 & 4 & 7 & 17 & 19 & 7 & 19 \\
\hline & $\begin{array}{l}\text { Collective } \\
\text { dismissals }\end{array}$ & 40 & 6 & 1 & 1 & 1 & 0 & 1 & 2 \\
\hline & $\begin{array}{l}\text { Permanent } \\
\text { contracts }\end{array}$ & 137 & 15 & 2 & 2 & 6 & 11 & 2 & 17 \\
\hline & $\begin{array}{l}\text { Temporary } \\
\text { contracts }\end{array}$ & 60 & 10 & 1 & 2 & 3 & 3 & 1 & 5 \\
\hline & $\begin{array}{l}\text { Other forms of } \\
\text { employment }\end{array}$ & 56 & 2 & 0 & 0 & 0 & 1 & 1 & 1 \\
\hline & Working hours & 73 & 3 & 0 & 1 & 2 & 0 & 1 & 0 \\
\hline \multicolumn{2}{|c|}{ Number of countries } & 37 & 14 & 3 & 5 & 9 & 15 & 6 & 21 \\
\hline
\end{tabular}


driven by the number of countries included in each region. For this reason, the continuation of the analysis will consider the different developing regions in a single aggregate.

\section{Empirical analysis}

\subsection{Determinants of labour market reforms}

The literature on the macroeconomic and institutional determinants of labour market reforms is relatively recent, but has already agreed on some important results. Great attention has been paid to the analysis of the timing of reforms over the business cycle (e.g. whether governments are more likely to implement reforms during economic crises) as well as to the role played by other institutional and economic factors (e.g. fixed exchange rate) (Turrini et al. 2015; Duval 2008). One important shortcoming of the existing studies is that they focus principally on a limited number of cases, particularly on developed economies, for which data on the intensity and scope of reforms is more easily available. However, developed and developing economies differ on a number of labour market aspects such as the importance of the informal economy, which influence the way in which labour market institutions affect economic and social outcomes (Sanchez Puerta 2010). As such, even similar labour market reforms are expected to generate a different impact and it is therefore plausible to hypothesize that the determinants behind their approval will also differ. For instance, if a change in the legislation to permanent employment contracts is deemed to influence the labour market only marginally (e.g. because the share of the labour force in formal employment and with a permanent contract is relatively small), then its approval might be less likely to depend on macroeconomic fluctuations or political pressures. Some studies have already sought to find the determinants of labour market reforms in both developed and developing countries (Campos and Nugent 2012). Despite their increased coverage, these analyses generally use as a dependent variable some indicators of labour market regulation rather than a measure of the degree of intensity of reform activity, which is difficult to obtain for developing economies. However, this different methodological approach changes the nature of the research question and is also more likely to be subject to endogeneity. Additionally and compared with previous studies, this paper conducts a more accurate assessment of the determinants of labour market reforms' approval over a number of dimensions, notably by (i) policy subdomain (e.g. temporary or permanent contracts); (ii) policy direction (i.e. increasing and decreasing protection); (iii) temporal horizon of the reform (i.e. temporary or permanent intervention); and (iv) coverage of the eligible population (i.e. two-tier or complete reform). Since not all areas of labour market reforms matter to the same extent to governments in times of crisis, it is plausible to hypothesize that their determinants will differ (Turrini et al. 2015). Intuitively, the macroeconomic determinants behind reforms that increase or decrease protection are likely to differ. Additionally, temporary reform measures might be conceived as emergency interventions and their nature, scope and determinants can differ from labour market interventions that are permanent and might be implemented to fix structural distortions in the labour market. Finally, labour market reforms targeting a specific group of the eligible population within each specific policy subdomain (the so-called two-tier reforms) might not necessitate the 
same political support as complete reforms that target the majority of the eligible population (Boeri and Garibaldi 2007).

In order to fill these research gaps, we use the information collected in the policy compendium described above to construct a measure of reform activism that is consistent between developed and developing economies and across different types of labour market reforms. In the choice of the covariates, we follow previous studies and include controls for country characteristics and the economic, fiscal and labour market situation, as well as the political and institutional context (Duval 2008; Turrini et al. 2015). Macroeconomic performances are captured by the inclusion of the difference between the annual GDP growth rate and its 5-year average, centred at the current year (the gap growth variable which takes positive values if the economy is accelerating). This variable is included as an alternative to the output gap, which has been generally used in the literature but is not available for a large set of developed and developing countries (Turrini et al. 2015). The expectations however remain the same, with countries that are experiencing a deceleration in GDP growth being more likely to implement reforms (Duval 2008). The underlying hypothesis is that deteriorating macroeconomic conditions make reforms necessary from an economic viewpoint as well as feasible in terms of political support (Duval and Elmeskov 2006). This positive relation between economic crises and reforms' activity is particularly strong for certain policy areas that are deemed to benefit the economy without generating negative side effects. However, the link becomes less evident for policy interventions that require the disbursement of public resources such as tax reforms, changes in benefit systems or precisely reforms of employment protection regulations (Høj et al. 2006; IMF 2004). The state of the labour market is controlled for by including the unemployment rate and its annual change (in percentage points). In the given context, the hypothesis put forward by previous studies is that countries facing negative (and deteriorating) labour market performances are more likely to approve EPL reforms (Duval and Elmeskov 2006). These reforms should be sensitive to both the overall state of the labour market (i.e. captured by the unemployment rate) and its trend (i.e. captured by the annual change). The state of public finances is accounted for by including a dummy which takes the value of 1 if the country is undertaking fiscal consolidation (Duval 2008). ${ }^{5}$ The expectation is that reforms (especially those that are costly to public finances) are more likely to occur in countries experiencing large budgetary surpluses (Duval and Elmeskov 2006). This has alternatively been related to the possibility for governments to compensate the losers of the reforms with side payments (Duval 2008; IMF 2004), the inability of governments facing poor public finances to spend their political support on structural reforms (Eichengreen and Wyplosz 1998), or the possibility to use a favourable fiscal position to stimulate internal demand in the wake of structural reforms (Fernandez and Rodrik 1991). Furthremore, we include a dummy for the presence of a fixed exchange rate regime (or the membership in a monetary union) in order to control for economic and institutional characteristics (Duval 2008; Turrini et al. 2015). In particular, the inability to fully manage the monetary policy at the national level has been generally associated with a greater need to implement structural reforms as a means to absorb macroeconomic shocks (Bean 1998). However, the literature has also found that membership in a monetary union can reduce the need to approve structural reforms by reducing governments' inflation bias (Calmfors 2001; Duval and Elmeskov 2006). We also include 
GDP per capita at the beginning of the period in order to capture structural country factors connected to the state of economic development. This should broadly take into account the link between economic and institutional developments and the related different role, of labour market institutions (Turrini et al. 2015). Finally, we account for institutional and political factors by including a set of variables describing political cycles and government partisanship orientation (Campos and Nugent 2012; Duval 2008). Given the large set of countries included in the analysis, we opt for a small set of comparable political characteristics. In particular, we add a dummy for the year in which a legislative election has taken place as well as a dummy for the year after the election. We hypothesize that reforms are less likely to occur in election years. Instead, they are more likely to take place just after elections since governments can take advantage of their initial popularity to pass electorally sensitive reforms (Turrini et al. 2015). However, this result is likely to differ substantially with respect to the nature, scope and direction of the reform (e.g. increasing or decreasing legislation). Additionally, we include a dummy for the political orientation of the government in power (i.e. taking the value of 1 for a centre-left government) (Duval 2008). This should capture differences in the weight given by opposite political parties to labour market reforms and institutions in general and to the direction of reforms in particular (Campos and Nugent 2012). A detailed description of the variables and their different sources is available in Appendix 2.

Furthermore, we also include year dummies in order to capture time-specific factors. Following Campos and Nugent (2012) and Turrini et al. (2015), we do not include country dummies as this would substantially reduce the degrees of freedom in the analysis (in this case, covering 110 countries). However, we include regional dummies to take into account regional trends in reforms' activity. ${ }^{6}$ Additionally, we verify the robustness of our models by confronting our baseline estimation with one including country fixed effects. Given that the limited time duration of the analysis does not allow instrumenting explanatory variables, we deal with the possible presence of endogeneity by including the main macroeconomic variables discussed above in lag or with their annual change. Following previous studies, we include other institutional and political variables with their contemporaneous values (Turrini et al. 2015). The model used is a negative binomial regression (NBREG) model. Repeated tests of fit between Poisson models, zero-inflated Poisson (ZIP) models, zero-inflated negative binomial (ZINB) models and the NBREG model indicate that the latter fits the best our data. The departure from the normal Poisson model is motivated by the fact that in the given context, the inclusion of a large set of developed and developing economies generates over-dispersion of the data connected to the presence in the database of a large amount of zeroes (i.e. due to the fact that not all countries passed reforms in all years and in each policy category). Unlike Poisson models, NBREG models correct for this over-dispersion by including a parameter that accounts for unobserved heterogeneity (Long and Freese 2001). Furthermore, following Turrini et al. (2015), we run each estimation by also using the ordinary least squares (OLS) model. This is done to both test the robustness of the results obtained with the NBREG model and benchmark our results with those of previous studies. Standard errors are clustered at the country level.

The results of the analysis show that unemployment has a positive and statistically significant effect on the probability to pass labour market reforms. This is true when the variable is included in lag, in difference, or using both the lag and the difference of 
unemployment in the same specification. Importantly, the inclusion of the lag (and/or the difference) of the unemployment rate does not substantially affect the statistical significance or coefficient of (alternatively) the difference (and/or the lag) of the unemployment rate-columns from 2 to 7 in Table 2. For this reason, we continue to estimate the models using both the lag and the difference of the unemployment rate. However, the results consistently show that the difference in the unemployment rate has a more significant effect than the lag in affecting the number of labour market reforms. Intuitively, this suggests that the implementation of reforms depends more on the rate of deterioration of the labour market rather than on its status. GDP fluctuations are instead not statistically associated with the number of labour market reforms approved-the so-called gap growth variable is not statistically significant in any specification. This suggests that during the period under consideration, reform activism has mostly followed labour market rather than GDP fluctuations. Another important result is that countries undertaking fiscal consolidation measures are more likely to implement labour market reforms. This finding is in contradiction with the previous literature that found a positive relation between the state of public finances and structural reforms but is in line with evidence from the recent crisis during which governments, especially in developed economies, simultaneously approved structural reforms and fiscal consolidation measures (Turrini et al. 2015). As expected, having a fixed exchange

Table 2 Determinants of the total number of labour market reforms

\begin{tabular}{|c|c|c|c|c|c|c|c|c|}
\hline & NBREG & OLS & NBREG & OLS & NBREG & OLS & NBREG & OLS \\
\hline \multirow[t]{2}{*}{ Unemployment (lag) } & $0.043^{* * *}$ & $0.062^{* *}$ & & & $0.042^{* * *}$ & $0.054^{* *}$ & 0.091 & 0.119 \\
\hline & $(0.012)$ & $(0.027)$ & & & $(0.014)$ & $(0.027)$ & $(0.076)$ & $(0.160)$ \\
\hline \multirow[t]{2}{*}{ Unemployment (difference) } & $0.102^{* *}$ & $0.293^{* *}$ & $0.096^{*}$ & $0.263^{*}$ & & & 0.107 & $0.269^{*}$ \\
\hline & $(0.051)$ & $(0.134)$ & $(0.056)$ & $(0.137)$ & & & $(0.078)$ & $(0.154)$ \\
\hline \multirow[t]{2}{*}{ Gap growth (lag) } & 0.033 & 0.030 & 0.030 & 0.024 & 0.020 & 0.008 & 0.042 & 0.034 \\
\hline & $(0.027)$ & $(0.027)$ & $(0.026)$ & $(0.026)$ & $(0.024)$ & $(0.021)$ & $(0.032)$ & $(0.029)$ \\
\hline \multirow[t]{2}{*}{ Fiscal consolidation } & $0.275^{*}$ & $0.367^{*}$ & $0.333^{* *}$ & $0.433^{* *}$ & $0.296^{* *}$ & 0.376 & 0.136 & 0.192 \\
\hline & $(0.143)$ & $(0.217)$ & $(0.139)$ & $(0.213)$ & $(0.146)$ & $(0.232)$ & $(0.185)$ & $(0.319)$ \\
\hline \multirow[t]{2}{*}{ Fixed exchange } & $0.382^{*}$ & $0.685^{* *}$ & $0.484^{* *}$ & $0.802^{* *}$ & $0.454^{* *}$ & $0.808^{* *}$ & $0.891^{* * *}$ & $0.842^{* * *}$ \\
\hline & $(0.223)$ & $(0.338)$ & $(0.232)$ & $(0.369)$ & $(0.230)$ & $(0.372)$ & $(0.233)$ & $(0.174)$ \\
\hline \multirow[t]{2}{*}{ Election year } & -0.087 & -0.127 & -0.093 & -0.134 & -0.106 & -0.115 & -0.047 & -0.109 \\
\hline & $(0.153)$ & $(0.169)$ & $(0.154)$ & $(0.172)$ & $(0.155)$ & $(0.163)$ & $(0.182)$ & $(0.196)$ \\
\hline \multirow[t]{2}{*}{ Post-election } & -0.113 & 0.051 & -0.108 & 0.028 & -0.123 & 0.049 & -0.040 & 0.052 \\
\hline & $(0.151)$ & $(0.210)$ & $(0.149)$ & $(0.206)$ & $(0.152)$ & $(0.213)$ & $(0.164)$ & $(0.234)$ \\
\hline \multirow[t]{2}{*}{ Ideology } & $0.237^{*}$ & 0.145 & $0.264^{*}$ & 0.224 & $0.263^{*}$ & 0.219 & 0.118 & -0.238 \\
\hline & $(0.137)$ & $(0.193)$ & $(0.136)$ & $(0.186)$ & $(0.143)$ & $(0.196)$ & $(0.201)$ & $(0.427)$ \\
\hline \multirow[t]{2}{*}{ GDP per capita (log, 2007) } & -0.147 & $-0.196^{*}$ & -0.119 & -0.128 & -0.140 & -0.182 & -1.133 & -0.262 \\
\hline & $(0.131)$ & $(0.115)$ & $(0.128)$ & $(0.097)$ & $(0.131)$ & $(0.110)$ & $(1.282)$ & $(2.595)$ \\
\hline Year dummies & Yes & Yes & Yes & Yes & Yes & Yes & Yes & Yes \\
\hline Regional dummies & Yes & Yes & Yes & Yes & Yes & Yes & No & No \\
\hline Country dummies & No & No & No & No & No & No & Yes & Yes \\
\hline (Pseudo) $R$-squared & 0.1031 & 0.1906 & 0.0969 & 0.1724 & 0.1009 & 0.1683 & 0.1776 & 0.3475 \\
\hline$N$ & 665 & 665 & 665 & 665 & 665 & 665 & 665 & 665 \\
\hline
\end{tabular}

Note: Dependent variable is the total number of reforms. Standard errors in parenthesis are clustered at the country level. $*^{* * * * * *}$ significant at the 10,5 and 1 per cent 
rate (or participating in a currency union) has a strong positive impact on the number of labour market reforms approved. Turning to the political variables reveals that when analysing the total number of reforms, neither the timing of elections (captured by the dummies for the year of election and the year after election) nor the political ideology of the government in power has a significant effect on the approval of reforms-the latter is significant only in the NBREG model. The GDP per capita variable also does not reach statistical significance, since the difference in reform trends between developed and developing economies is likely to be captured by the inclusion of the regional dummies (not reported in the table). Finally, we propose alternative specifications including country dummies rather than regional dummies and always on top of the years' effects, columns 8 and 9 in Table 2 . All coefficients remain very close to those estimated without country fixed effects. However, most of them lose statistical significance with the exception of the fixed exchange rate dummy in both the NBREG and OLS models and the difference in unemployment in the OLS specification. Following Turrini et al. (2015), we interpret this as a loss in the precision of the estimation due to the reduced degrees of freedom (in the present context, related to the inclusion of dummies for 110 countries) and continue estimating the results with regional (rather than country) fixed effects.

In the next step, we estimate the full model separately for reforms that increase and decrease labour regulation (i.e. by direction), for those that have a temporary or permanent implementation prospect (i.e. by temporal horizon) and for those that target the complete eligible population or rather a share of it (i.e. by coverage)-Table 3. The results confirm our initial hypothesis on differences in the determinants of reforms decreasing/increasing labour legislation and show that the unemployment rate (both in lag and difference) is positive and statistically significant only in the specification considering reforms that decrease the strictness of labour legislation. This suggests that in times of crisis, governments have implemented deregulatory labour market reforms-rather than labour market reforms in general. By contrast, the implementation of labour market reforms reinforcing the level of protection is not influenced by labour market or macroeconomic performances, while being positively associated with the presence of a fixed exchange rate regime and the presence of a left-wing coalition in power. Interestingly and according to our expectations, the coefficient for the dummy of the election year is positive for reforms increasing labour market regulation and negative for those decreasing it. However, in both cases, it does not reach statistical significance. Turning to the temporal horizon of the reforms (i.e. permanent or temporary reforms), we are not able to detect any difference in the determinants of their approval. Indeed, both types of reforms are positively associated with the lag and the change in unemployment rate. This might be related to the relative scarcity of temporary reforms in the policy compendium which account for only $8 \%$ of total number of reforms. Finally, we investigate separately the determinants of complete versus two-tier labour market reforms. The results reveal that the determinants behind the approval of these types of reforms indeed differ, with complete reforms not being connected to fiscal consolidation measures and the fixed exchange rate regime.

Finally, we investigate the determinants of the approval of reforms by subdomain of labour legislation (Table 4). Unlike previous studies that concentrate only on 


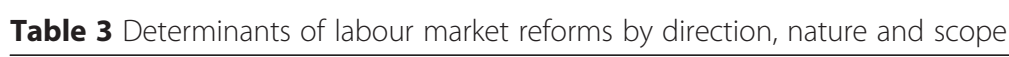

\begin{tabular}{|c|c|c|c|c|c|c|c|c|c|c|c|c|}
\hline & \multicolumn{4}{|c|}{ Direction } & \multicolumn{4}{|c|}{ Temporal horizon } & \multicolumn{4}{|l|}{ Coverage } \\
\hline & \multicolumn{2}{|c|}{ Increasing reforms } & \multicolumn{2}{|c|}{ Decreasing reforms } & \multicolumn{2}{|c|}{ Temporary reforms } & \multicolumn{2}{|c|}{ Permanent reforms } & \multicolumn{2}{|c|}{ Complete reforms } & \multicolumn{2}{|c|}{ Two-tier reforms } \\
\hline & NBREG & OLS & NBREG & OLS & NBREG & OLS & NBREG & OLS & NBREG & OLS & NBREG & OLS \\
\hline \multirow[t]{2}{*}{ Unemployment (lag) } & 0.015 & 0.006 & $0.069^{* * *}$ & $0.057^{* *}$ & $0.157^{* * *}$ & $0.013^{* *}$ & $0.036^{* * *}$ & $0.049 * *$ & $0.055^{* * *}$ & $0.048^{* *}$ & 0.015 & $0.014^{*}$ \\
\hline & $(0.012)$ & $(0.006)$ & $(0.019)$ & $(0.025)$ & $(0.031)$ & $(0.006)$ & $(0.012)$ & $(0.022)$ & $(0.014)$ & $(0.020)$ & $(0.023)$ & $(0.008)$ \\
\hline \multirow[t]{2}{*}{ Unemployment (difference) } & 0.026 & 0.027 & $0.116^{*}$ & $0.266^{* *}$ & $0.174^{* *}$ & 0.046 & $0.098^{*}$ & $0.248^{* *}$ & $0.109^{*}$ & $0.187^{* *}$ & $0.115^{*}$ & $0.106^{*}$ \\
\hline & $(0.063)$ & $(0.037)$ & $(0.064)$ & $(0.118)$ & $(0.080)$ & $(0.028)$ & $(0.052)$ & $(0.115)$ & $(0.056)$ & $(0.084)$ & $(0.063)$ & $(0.057)$ \\
\hline \multirow[t]{2}{*}{ Gap growth (lag) } & 0.023 & 0.006 & 0.025 & 0.024 & 0.096 & 0.003 & 0.030 & 0.027 & 0.022 & 0.017 & $0.059^{*}$ & 0.012 \\
\hline & $(0.025)$ & $(0.009)$ & $(0.045)$ & $(0.021)$ & $(0.063)$ & $(0.003)$ & $(0.028)$ & $(0.025)$ & $(0.032)$ & $(0.020)$ & $(0.033)$ & $(0.009)$ \\
\hline \multirow[t]{2}{*}{ Fiscal consolidation } & 0.262 & 0.134 & 0.288 & 0.234 & 0.053 & 0.045 & $0.282^{*}$ & 0.322 & 0.248 & 0.214 & $0.317^{*}$ & $0.153^{*}$ \\
\hline & $(0.163)$ & $(0.090)$ & $(0.205)$ & $(0.163)$ & $(0.316)$ & $(0.034)$ & $(0.155)$ & $(0.213)$ & $(0.161)$ & $(0.154)$ & $(0.175)$ & $(0.078)$ \\
\hline \multirow[t]{2}{*}{ Fixed exchange } & $0.340^{* *}$ & $0.215^{* *}$ & $0.539^{*}$ & 0.470 & 0.349 & $0.089^{*}$ & 0.356 & $0.596^{*}$ & 0.258 & 0.351 & $0.677^{* *}$ & $0.334^{* *}$ \\
\hline & $(0.173)$ & $(0.095)$ & $(0.325)$ & $(0.291)$ & $(0.465)$ & $(0.049)$ & $(0.235)$ & $(0.318)$ & $(0.234)$ & $(0.231)$ & $(0.269)$ & $(0.135)$ \\
\hline \multirow[t]{2}{*}{ Election year } & 0.028 & 0.016 & -0.131 & -0.142 & -0.281 & -0.019 & -0.099 & -0.108 & -0.155 & -0.117 & 0.057 & -0.010 \\
\hline & $(0.186)$ & $(0.083)$ & $(0.214)$ & $(0.118)$ & $(0.501)$ & $(0.033)$ & $(0.167)$ & $(0.163)$ & $(0.166)$ & $(0.120)$ & $(0.218)$ & $(0.071)$ \\
\hline \multirow[t]{2}{*}{ Post-election } & -0.114 & -0.010 & -0.014 & 0.062 & -0.154 & 0.003 & -0.136 & 0.048 & -0.169 & 0.021 & 0.086 & 0.031 \\
\hline & $(0.164)$ & $(0.079)$ & $(0.218)$ & $(0.161)$ & $(0.418)$ & $(0.026)$ & $(0.164)$ & $(0.212)$ & $(0.197)$ & $(0.167)$ & $(0.179)$ & $(0.069)$ \\
\hline \multirow[t]{2}{*}{ Ideology } & $0.345^{* *}$ & $0.145^{*}$ & 0.017 & 0.001 & 0.100 & 0.011 & $0.260^{*}$ & 0.134 & $0.340^{* *}$ & 0.161 & -0.019 & -0.016 \\
\hline & $(0.155)$ & $(0.077)$ & $(0.218)$ & $(0.145)$ & $(0.338)$ & $(0.035)$ & $(0.145)$ & $(0.180)$ & $(0.149)$ & $(0.138)$ & $(0.191)$ & $(0.074)$ \\
\hline \multirow[t]{2}{*}{ GDP per capita $(\log , 2007)$} & -0.030 & -0.023 & -0.334 & $-0.173^{*}$ & 0.127 & -0.017 & -0.138 & $-0.179^{*}$ & -0.147 & -0.127 & $-0.339^{*}$ & $-0.069^{*}$ \\
\hline & $(0.112)$ & $(0.037)$ & $(0.230)$ & $(0.095)$ & $(0.305)$ & $(0.016)$ & $(0.133)$ & $(0.106)$ & $(0.153)$ & $(0.087)$ & $(0.184)$ & $(0.038)$ \\
\hline Year dummies & Yes & Yes & Yes & Yes & Yes & Yes & Yes & Yes & Yes & Yes & Yes & Yes \\
\hline Country dummies & No & No & No & No & No & No & No & No & No & No & No & No \\
\hline Regional dummies & Yes & Yes & Yes & Yes & Yes & Yes & Yes & Yes & Yes & Yes & Yes & Yes \\
\hline (Pseudo) $R$-squared & 0.0583 & 0.0924 & 0.1611 & 0.1817 & 0.2636 & 0.1325 & 0.0913 & 0.1693 & 0.0861 & 0.1476 & 0.1945 & 0.1999 \\
\hline N & 665 & 665 & 665 & 665 & 665 & 665 & 665 & 665 & 665 & 665 & 665 & 665 \\
\hline
\end{tabular}

Note: Dependent variable is the total number of reforms for each category identified. Standard errors in parenthesis are clustered at the country leve.

$* / * * * * *$ significant at the 10,5 and 1 per cent 
Table 4 Determinants of labour reforms by policy domain

\begin{tabular}{|c|c|c|c|c|c|c|c|c|c|c|c|c|}
\hline & \multicolumn{2}{|c|}{ Collective bargaining } & \multicolumn{2}{|c|}{ Collective dismissals } & \multicolumn{2}{|c|}{ Permanent contracts } & \multicolumn{2}{|c|}{ Temporary contracts } & \multicolumn{2}{|c|}{ Other forms of employment } & \multicolumn{2}{|c|}{ Working hours } \\
\hline & NBREG & OLS & NBREG & OLS & NBREG & OLS & NBREG & OLS & NBREG & OLS & NBREG & OLS \\
\hline \multirow[t]{2}{*}{ Unemployment (lag) } & $0.046^{* * *}$ & $0.015^{* *}$ & $0.110^{* * *}$ & $0.013^{*}$ & $0.041^{* *}$ & 0.015 & $0.059^{* * *}$ & $0.008^{* * *}$ & -0.024 & 0.002 & $0.055^{* *}$ & $0.009^{*}$ \\
\hline & $(0.015)$ & $(0.006)$ & $(0.023)$ & $(0.007)$ & $(0.020)$ & $(0.009)$ & $(0.020)$ & $(0.003)$ & $(0.033)$ & $(0.002)$ & $(0.028)$ & $(0.005)$ \\
\hline \multirow[t]{2}{*}{ Unemployment (difference) } & $0.200^{* * *}$ & $0.097^{* *}$ & 0.090 & 0.031 & -0.001 & 0.050 & 0.166 & 0.049 & 0.072 & 0.016 & $0.130^{*}$ & $0.050^{*}$ \\
\hline & $(0.053)$ & $(0.040)$ & $(0.083)$ & $(0.027)$ & $(0.080)$ & $(0.046)$ & $(0.101)$ & $(0.034)$ & $(0.087)$ & $(0.014)$ & $(0.071)$ & $(0.029)$ \\
\hline \multirow[t]{2}{*}{ Gap growth (lag) } & 0.054 & 0.012 & -0.016 & -0.000 & 0.023 & 0.007 & 0.001 & 0.001 & 0.047 & 0.004 & 0.076 & 0.006 \\
\hline & $(0.042)$ & $(0.009)$ & $(0.074)$ & $(0.005)$ & $(0.039)$ & $(0.010)$ & $(0.048)$ & $(0.006)$ & $(0.061)$ & $(0.005)$ & $(0.070)$ & $(0.005)$ \\
\hline \multirow[t]{2}{*}{ Fiscal consolidation } & 0.175 & 0.067 & 0.166 & 0.023 & 0.292 & 0.105 & 0.137 & 0.027 & 0.334 & 0.058 & 0.353 & $0.087^{*}$ \\
\hline & $(0.214)$ & $(0.070)$ & $(0.322)$ & $(0.037)$ & $(0.215)$ & $(0.084)$ & $(0.331)$ & $(0.054)$ & $(0.304)$ & $(0.041)$ & $(0.276)$ & $(0.045)$ \\
\hline \multirow[t]{2}{*}{ Fixed exchange } & 0.316 & 0.122 & 0.527 & 0.072 & 0.244 & 0.121 & 0.575 & 0.127 & $0.734^{* *}$ & $0.123^{* *}$ & 0.389 & $0.122^{*}$ \\
\hline & $(0.270)$ & $(0.081)$ & $(0.547)$ & $(0.058)$ & $(0.289)$ & $(0.130)$ & $(0.380)$ & $(0.091)$ & $(0.346)$ & $(0.057)$ & $(0.359)$ & $(0.069)$ \\
\hline \multirow[t]{2}{*}{ Election year } & -0.227 & -0.052 & -0.366 & -0.019 & -0.149 & -0.043 & 0.393 & 0.017 & 0.085 & 0.008 & -0.275 & -0.037 \\
\hline & $(0.242)$ & $(0.054)$ & $(0.385)$ & $(0.026)$ & $(0.218)$ & $(0.059)$ & $(0.273)$ & $(0.044)$ & $(0.328)$ & $(0.036)$ & $(0.356)$ & $(0.038)$ \\
\hline \multirow[t]{2}{*}{ Post-election } & 0.062 & 0.043 & 0.441 & 0.063 & -0.312 & -0.035 & -0.178 & -0.048 & 0.083 & 0.013 & 0.005 & 0.016 \\
\hline & $(0.207)$ & $(0.062)$ & $(0.277)$ & $(0.039)$ & $(0.252)$ & $(0.085)$ & $(0.390)$ & $(0.058)$ & $(0.315)$ & $(0.041)$ & $(0.323)$ & $(0.043)$ \\
\hline \multirow[t]{2}{*}{ Ideology } & 0.147 & 0.037 & -0.379 & -0.031 & 0.204 & 0.032 & 0.090 & 0.003 & $0.578^{*}$ & 0.050 & 0.498 & 0.054 \\
\hline & $(0.216)$ & $(0.069)$ & $(0.326)$ & $(0.034)$ & $(0.210)$ & $(0.066)$ & $(0.238)$ & $(0.029)$ & $(0.319)$ & $(0.039)$ & $(0.306)$ & $(0.051)$ \\
\hline \multirow[t]{2}{*}{ GDP per capita (log, 2007) } & $-0.314^{* *}$ & $-0.069^{* *}$ & -0.362 & -0.029 & -0.082 & -0.045 & -0.042 & -0.014 & $-0.643^{*}$ & -0.016 & -0.188 & -0.021 \\
\hline & $(0.153)$ & $(0.033)$ & $(0.419)$ & $(0.024)$ & $(0.182)$ & $(0.039)$ & $(0.229)$ & $(0.020)$ & $(0.361)$ & $(0.016)$ & $(0.362)$ & $(0.021)$ \\
\hline Year dummies & Yes & Yes & Yes & Yes & Yes & Yes & Yes & Yes & Yes & Yes & Yes & Yes \\
\hline Country dummies & No & No & No & No & No & No & No & No & No & No & No & No \\
\hline Regional dummies & Yes & Yes & Yes & Yes & Yes & Yes & Yes & Yes & Yes & Yes & Yes & Yes \\
\hline (Pseudo) $R$-squared & 0.0672 & 0.0912 & 0.2219 & 0.0919 & 0.1232 & 0.1246 & 0.0978 & 0.0544 & 0.2485 & 0.1186 & 0.2392 & 0.1560 \\
\hline N & 665 & 665 & 665 & 665 & 665 & 665 & 665 & 665 & 665 & 665 & 665 & 665 \\
\hline
\end{tabular}

Note: Dependent variable is the total number of reforms for each category identified. Standard errors in parenthesis are clustered at the country level

$* / * * * * *$ significant at the 10,5 and 1 per cent 
estimating the responsiveness of institutions to economic changes at the aggregate level often in conjunction with other types of labour interventions (e.g. unemployment benefits or active policies), we test whether there is variation in how different subdomains of labour market legislation are reformed. Our strategy builds on the idea that since labour market legislation covers a large number of regulations that are heterogeneous in scope, in times of crisis governments will seek to adjust only the subdomains that are thought not to have a negative impact on the economy; or to reinforce the legislation for those that are being disproportionately affected by the crisis. Our results reveal that the institutional and macroeconomic determinants of reforms vary across different labour market subdomains. In particular, (the lag of) the unemployment rate is a significant predictor of the likelihood to pass reforms in the areas of collective bargaining, collective dismissals, permanent contracts, temporary contracts and working hours, while it does not reach the significance thresholds in the case of other forms of employment. This might be due to the fact that in the case of the latter domain, governments adopt changes in order to address structural rather than cyclical challenges in the labour markets (Berg 2015). At the same time, working hours is one of the few policy subdomains (together with collective bargaining) where both the lag and the difference in unemployment rates are statistically significant. This might reflect the fact that changes in the regulation of working hours (e.g. increasing autonomy for employers to set working times) are traditional crisis-related interventions (e.g. to limit dismissals). The rest of the macroeconomic and institutional variables lose part of their statistical significance when analysing the determinants of reforms by subdomain, probably due to the reduction in statistical precision brought about by dividing the sample.

Differences in the estimation results between developed and developing economies can be consulted in Appendix 1, where the tables presented above have been reproduced separately for the two groups of countries. Overall, the model performs better in developed economies where the majority of reforms have taken place. In this group of countries, the analysis confirms most of the results with respect to the relation between unemployment rates and reforms' approval, including the differences observed between reforms increasing and decreasing regulation. Additionally, for developed economies, our analysis confirms the initial hypothesis that temporary reforms (compared to permanent reforms) are more sensitive to labour market performances (e.g. emergency measures) as both the lag and the difference in unemployment rates are statistically significant. Turning to developing economies, the model suggests that reforms' approval does not necessarily follow labour market and GDP performances as closely as in developed economies. This might be related to the lower relevance of labour market indicators (i.e. unemployment rate) in capturing the level of labour market distress in developing countries as well as to the initial hypothesis that labour market reforms in developing economies respond to a lower extent to macroeconomic and labour market outcomes-as the changes in the legislation affect only a limited share of the labour force (e.g. due to informality). However, other institutional and political considerations seem to matter in explaining reforms' approval in developing economies. In particular, our analysis reveals 
that in contrast with the overall sample reforms' approval in developing economies is negatively associated with being in the year after the election. This is largely driven by the result obtained when considering reforms increasing labour market regulation, which, according to our expectations, are less likely to occur just after an election has taken place. Similarly, in the case of developing economies, the dummy for a left-wing government in power is positive and statistically significant in the specification including reforms that increase labour legislation-while for advanced economies, this is non-significant.

\subsection{Short-term effects of labour market reforms}

While the above analysis has shown that countries have reacted to the recent crisis through an intensive reform activity in the labour market domain, from a policy perspective the most important aspect is to evaluate whether the changes passed in the recent years had the desired effects of improving labour market performance. There is a rich literature discussing the effects of EPL on labour market outcomes. On the one hand, a number of studies have found no statistically significant effects of the stringency of labour legislation on employment and unemployment rates. The World Bank (2013) notes that the estimated effect of labour market regulations on macroeconomic outcomes varies across countries but in all cases, it is extremely modest. The same conclusion has been recently reached amongst others by IMF (2015), ILO (2015a) and Avdagic and Salardi (2013). This result has been related to a number of different factors. Some studies have pointed to the so-called plateau effect, suggesting that most countries have reached a level of employment protection such that changes to the legislation produce only very limited effects on employment outcomes (World Bank 2013; ILO 2012). Alternatively, other studies have connected the lack of statistically significant effects to difficulties stemming from the precise measurement of the legal and effective stringency of labour legislation (IMF 2015). Finally, a number of studies have argued that while EPL has no effect on overall employment or unemployment rates, it does have an effect on some specific categories of workers such as youth and women (Bassanini and Duval 2006). However, other studies have found that employment regulation does have a negative impact on overall labour market performances. In a cross-national study of labour market regulations in 73 developed and developing countries, Feldmann (2009) finds that stricter labour market regulations increase unemployment. Likewise, BernalVerdugo et al. (2012) argue that increased labour market flexibility can have an important effect in reducing unemployment. However, the authors are careful in interpreting deregulation as a necessary route for increasing employment and propose that labour market policies "should be properly designed to also improve the quality of employment and to minimize the possible negative short-term effects" (Bernal-Verdugo et al. 2012). Furthermore, Nickell et al. (2005) find that in the case of the OECD economies, employment protection raises unemployment through its impact on unemployment persistence. The identified effect is strong, with $55 \%$ of unemployment rise being explained by changes in labour market institutions (Nickell et al. 2005). 
In comparison with the studies outlined above, the purpose of the present analysis is not to identify the general equilibrium effects of the overall level of stringency of EPL on aggregate labour market outcomes. For that kind of analysis, indicators of EPL rather than compendiums of reforms are the most suitable instruments. Rather, this paper focuses on understanding the short-term effects of policy changes on labour market outcomes. This question has only recently started to be investigated in the literature, with studies that have followed different methodologies (see Boeri et al. 2015 for a review). For example, Cacciatore et al. (2012) use a DSGE model and find that in the short term, labour market reforms increase unemployment and reduce wages, while in the long run they have positive effects on GDP and consumption and consequently on labour market performances. More similar to the methodology of the present analysis, Bouis et al. (2012) identify reforms to have taken place if the annual change in the unemployment benefits' replacement rate is above two standard deviations of the average change across countries. With this indicator, they report for a panel of OECD countries that reductions in the unemployment benefit replacement rates are positively correlated with increases in employment rates. However, they also find that reforms impact differently various categories of workers, with reductions in unemployment benefit duration being associated with a reduction in employment for older workers. Additionally, their findings suggest that reforms might have negative short-run effects if implemented during economic downturns. The presence of short-term negative effects of labour market reforms is also confirmed by Sertic et al. (2015) for EU member states. Furthermore, in a panel of 23 OECD countries Bassanini (2015) finds that procompetitive product market reforms have short-term negative effects on employment, with the negative effects materializing only if reforms are implemented during downturns.

We contribute to this literature by leveraging the information contained in the compendium described in Section 2 and estimate the short-term effects of labour market reforms on unemployment rates. We focus on the short-term effect of reforms on unemployment rather than employment as previous studies have found that deregulatory labour market reforms increase lay-off rates in the short run (Boeri et al. 2015; Cacciatore et al. 2012). Although the use of count data as a measure of labour market regulation clearly represents a limitation of the proposed methodology, a similar approach has already been used in a number of economic applications to explore the effects of policy interventions. These contributions include the evaluation of the impact of labour market reforms (Bouis et al. 2012) and of monetary and fiscal policies as well as applications in the areas of health economics (Riphahn et al. 2003) and international economics (List 2001). Building on this literature, we construct different measures of labour market regulation by separately including as covariates (i) the total number of reforms that increase/decrease regulation and (ii) the difference between the number of reforms decreasing legislation and those increasing it (the reform stance variable). The rest of the covariates included in the analysis follows the rich literature on the cross-country effects of EPL on labour market outcomes (Bassanini and Duval 2006; Bertola et al. 2007; Daveri and Tabellini 2000). In 
particular, we include the gap growth variable described in Section 3.1 as a measure of macroeconomic fluctuations. Additionally, we control for existing levels of labour market regulation and the tax rate (Bassanini and Duval 2006 and literature therein). ${ }^{7}$ While the hypothesis concerning the relation between labour market regulation and unemployment has already been discussed at the beginning of this section, we expect the tax rate to be positively associated with unemployment rates (Elmeskov et al. 1998). Following Avdagic and Salardi (2013) and Nickell et al. (2005), we opt for a generalized least squares (GLS) model, while allowing for panel-level heteroscedastic standard errors and autocorrelation of the first order. For the purpose of the analysis, we do not distinguish between policy subdomains because it would be difficult to disentangle the effects of each area of intervention on the overall unemployment rate. Furthermore, since the effect of legal regulation is likely to take some time until it impacts unemployment rates, we lag the different variables that measure (de)regulation. As the purpose of the present exercise is to examine only the short-term impact of labour market reforms on unemployment, we use as a dependent variable the change in unemployment rate (Daveri and Tabellini 2000). We include country and year fixed effects to control for country-specific averages of omitted institutions and for common shocks across countries (Bassanini and Duval 2006).

The results of the baseline specifications are presented in Table 5. They reveal that the change in the unemployment rate is negatively associated only with the gap growth variable (i.e. countries experiencing an acceleration in GDP growth are less likely to have an increase in the unemployment rate). All the measures of labour market regulation (included separately, columns 2 to 5 ) do not have a statistically significant effect on unemployment. The results do not vary when considering the overall sample as well as developed and developing countries separately. Moreover, the indicators of EPL and the labour tax rate are either not statistically significant or have a very low magnitude. This is in line with results of previous studies that have used as dependent variable the difference rather than the level of unemployment (Daveri and Tabellini 2000). This result can be explained by the fact that-although EPL and tax rates might have an impact on unemployment-it is less likely that they will influence its short-term fluctuations.

Finally, we test whether structural reforms have negative short-term effects when implemented during recessions. In order to test this hypothesis, we follow Bouis et al. (2012) and augment the baseline specification with an interaction term between the variable that captures the macroeconomic fluctuations (the gap growth) and the indicator of labour market deregulation. Evaluating the effects of reforms over the business cycle requires computing the marginal effects of the indicator of deregulation for different states of economic activity. We do so by calculating the marginal effects of reforms on the change in unemployment at the different deciles of the gap growth variable. This represents a more detailed specification compared to Bouis et al. (2012), who look only at the median, maximum and minimum, with the latter two likely to be sensitive to outliers. However and given that the gap growth variable is ultimately unobserved, we consider this final part of the analysis as suggestive rather than conclusive 
Table 5 Baseline equation for the difference in unemployment

\begin{tabular}{|c|c|c|c|c|c|c|c|c|c|c|c|c|}
\hline \multirow[b]{2}{*}{ Reforms decreasing (lag) } & \multicolumn{4}{|c|}{ All countries } & \multicolumn{4}{|c|}{ Developed economies } & \multicolumn{4}{|c|}{ Developing economies } \\
\hline & 0.013 & & 0.014 & & 0.039 & & 0.043 & & -0.053 & & -0.063 & \\
\hline & $(0.028)$ & & $(0.028)$ & & $(0.035)$ & & $(0.038)$ & & $(0.046)$ & & $(0.047)$ & \\
\hline \multirow[t]{2}{*}{ Reforms increasing (lag) } & & -0.007 & -0.014 & & & 0.011 & -0.005 & & & 0.024 & $0.039^{*}$ & \\
\hline & & $(0.030)$ & $(0.034)$ & & & $(0.074)$ & $(0.084)$ & & & $(0.024)$ & $(0.022)$ & \\
\hline \multirow[t]{2}{*}{ Reform stance (lag) } & & & & 0.024 & & & & 0.033 & & & & -0.033 \\
\hline & & & & $(0.024)$ & & & & $(0.038)$ & & & & $(0.022)$ \\
\hline \multirow[t]{2}{*}{ Gap growth } & $-0.181^{* * *}$ & $-0.173^{* * *}$ & $-0.178^{* * *}$ & $-0.185^{* * *}$ & $-0.342^{* * *}$ & $-0.337^{* * *}$ & $-0.340^{* * *}$ & $-0.352^{* * *}$ & $-0.096^{* * *}$ & $-0.097^{* * *}$ & $-0.096^{* * *}$ & $-0.098^{* * *}$ \\
\hline & $(0.009)$ & $(0.010)$ & $(0.010)$ & $(0.009)$ & $(0.035)$ & $(0.034)$ & $(0.035)$ & $(0.034)$ & $(0.007)$ & $(0.007)$ & $(0.007)$ & $(0.007)$ \\
\hline \multirow[t]{2}{*}{ EPL indicator } & $0.007^{* *}$ & $0.007^{* *}$ & $0.007^{* *}$ & $0.007^{* *}$ & 0.005 & 0.004 & 0.005 & 0.005 & 0.005 & 0.005 & 0.004 & 0.004 \\
\hline & $(0.003)$ & $(0.003)$ & $(0.003)$ & $(0.003)$ & $(0.007)$ & $(0.007)$ & $(0.007)$ & $(0.008)$ & $(0.005)$ & $(0.005)$ & $(0.005)$ & $(0.005)$ \\
\hline \multirow[t]{2}{*}{ Tax rate } & 0.003 & 0.003 & 0.003 & 0.004 & $0.020^{*}$ & 0.018 & $0.021^{*}$ & 0.020 & $-0.006^{* *}$ & $-0.006^{*}$ & $-0.006^{* *}$ & $-0.006^{*}$ \\
\hline & $(0.004)$ & $(0.004)$ & $(0.004)$ & $(0.004)$ & $(0.012)$ & $(0.012)$ & $(0.012)$ & $(0.012)$ & $(0.003)$ & $(0.003)$ & $(0.003)$ & $(0.003)$ \\
\hline Year dummies & Yes & Yes & Yes & Yes & Yes & Yes & Yes & Yes & Yes & Yes & Yes & Yes \\
\hline Country dummies & Yes & Yes & Yes & Yes & Yes & Yes & Yes & Yes & Yes & Yes & Yes & Yes \\
\hline Regional dummies & No & No & No & No & No & No & No & No & No & No & No & No \\
\hline N & 372 & 372 & 372 & 372 & 144 & 144 & 144 & 144 & 228 & 228 & 228 & 228 \\
\hline
\end{tabular}

Note: Dependent variable is the annual change in unemployment (in percentage points). GLS model correcting for panel heteroscedasticity and autocorrelation (AR1)

$* / * * * * * *$ significant at the 10,5 and 1 per cent 
Table 6 Equation for the difference in unemployment at different points of the business cycle

\begin{tabular}{llll}
\hline & All & Developed & Developing \\
\hline Panel A. Estimation results & & & \\
Reforms decreasing (lag) & 0.0002 & 0.028 & -0.038 \\
& $(0.028)$ & $(0.036)$ & $(0.051)$ \\
Gap growth & $-0.178^{* *}$ & $-0.326^{* * *}$ & $-0.098^{* * *}$ \\
EPL indicator & $(0.008)$ & $(0.037)$ & $(0.008)$ \\
& $0.008^{* * *}$ & 0.005 & 0.04 \\
Tax rate & $(0.002)$ & $(0.007)$ & $(0.005)$ \\
& 0.001 & $0.023^{* *}$ & $-0.006^{* *}$ \\
Reforms decreasing (lag)*Gap growth & $(0.003)$ & $(0.011)$ & $(0.003)$ \\
& $-0.023^{* *}$ & -0.019 & 0.030 \\
& $(0.009)$ & $(0.013)$ & $(0.023)$
\end{tabular}

Panel B: Marginal effects of the impact of reforms decreasing labour legislation at different percentiles of the gap growth variable

\begin{tabular}{|c|c|c|c|}
\hline \multirow[t]{2}{*}{ Min } & $0.0394^{* *}$ & $0.342^{*}$ & -0.547 \\
\hline & $(0.016)$ & $(0,204)$ & $(0.377)$ \\
\hline \multirow[t]{2}{*}{ p10 } & $0.118^{* *}$ & $0.144^{*}$ & $-0.181^{*}$ \\
\hline & $(0.050)$ & $(0.078)$ & $(0.106)$ \\
\hline \multirow[t]{2}{*}{ p20 } & $0.062^{*}$ & $0.092^{*}$ & $-0.106^{*}$ \\
\hline & $(0.033)$ & $(0.049)$ & $(0.061)$ \\
\hline \multirow[t]{2}{*}{ p30 } & 0.031 & $0.063^{*}$ & -0.073 \\
\hline & $(0.027)$ & $(0.038)$ & $(0.049)$ \\
\hline \multirow[t]{2}{*}{$\mathrm{p} 40$} & 0.014 & 0.043 & -0.052 \\
\hline & $(0.027)$ & $(0.035)$ & $(0.048)$ \\
\hline \multirow[t]{2}{*}{ p50 } & -0.001 & 0.030 & -0.035 \\
\hline & $(0.028)$ & $(0.035)$ & $(0.051)$ \\
\hline \multirow[t]{2}{*}{ p60 } & -0.013 & 0.011 & -0.023 \\
\hline & $(0.03)$ & $(0.039)$ & $(0.055)$ \\
\hline \multirow[t]{2}{*}{ p70 } & -0.027 & -0.004 & -0.010 \\
\hline & $(0.033)$ & $(0.044)$ & $(0.059)$ \\
\hline \multirow[t]{2}{*}{ p80 } & -0.049 & -0.012 & 0.027 \\
\hline & $(0.039)$ & $(0.049)$ & $(0.080)$ \\
\hline \multirow[t]{2}{*}{ p90 } & -0.071 & -0.024 & 0.056 \\
\hline & $(0.046)$ & $(0.054)$ & $(0.099)$ \\
\hline \multirow[t]{2}{*}{ Max } & $-0.211^{* *}$ & -0.122 & 0.236 \\
\hline & (0.099) & $(0.112)$ & $(0.228)$ \\
\hline Year dummies & Yes & Yes & Yes \\
\hline Country dummies & Yes & Yes & Yes \\
\hline Regional dummies & No & No & No \\
\hline N & 372 & 144 & 228 \\
\hline
\end{tabular}

Note: Dependent variable is the annual change in unemployment (in percentage points). GLS model correcting for panel heteroscedasticity and autocorrelation (AR1)

$*^{* * * * * * *}$ significant at the 10,5 and 1 per cent 
(Bouis et al. 2012). The results reveal that for low levels of the gap growth variable (i.e. when the economy is contracting), introducing deregulatory labour market reforms has negative short-term effects (i.e. positive effect on the change in unemployment). By contrast, when these reforms are introduced during periods of economic stability or economic expansion, there are no (either positive or negative) short-term effects. These results hold when analysing the full sample of countries (until the 20th percentile of the gap growth variable) as well as when looking only at developed economies (until the 30th percentile). By contrast, the implementation of deregulatory labour market reforms seems not to have any differential effect over the business cycle in developing countries (Table 6). ${ }^{8}$

\section{Conclusions}

This paper has presented evidence from a novel policy compendium mapping reforms in the labour market domain in 110 developed and developing economies between 2008 and 2014. The methodology followed to compile and code the compendium follows previous literature, while applying it to a larger set of countries and a narrower set of interventions. Our descriptive analysis reveals that the number of interventions to labour legislation has increased in the first years after the beginning of the crisis and that the majority of the reforms have been approved in developed economies and EU member states in particular. Moreover, the majority of the interventions ( $55 \%$ ) have decreased existing levels of regulation, although this trend largely differs across regions, with many developing economies actually reinforcing their legislation. Additionally, most of the interventions have been of permanent (rather than temporary) nature and they have targeted the entire eligible population (rather than a specific subset of the eligible population). Focusing the analysis only on labour legislation reforms allows us to obtain a more accurate understanding of reforms' trends across labour market regulation subdomains. In particular, we show that the majority of the interventions have been in the area of permanent contracts (30\%), followed by collective bargaining $(27 \%)$ and temporary contracts $(13 \%)$. However, these trends largely differ across regions (e.g. developing economies have mostly reformed collective bargaining). At the same time, the deregulatory trend has not concerned all labour subdomains equally (e.g. legislation on other forms of employment has generally been reinforced).

Using data from the compendium, the paper contributes to the literature by looking at (i) the macroeconomic and institutional determinants of labour market reforms and (ii) the short-term effects of the interventions. The results show that the approval of reforms is positively associated with unemployment rates (both in levels and changes), signalling that poor labour market performances lead governments to reform labour legislation. Additionally, countries implementing fiscal consolidation measures and countries with a fixed exchange regime are more likely to pass labour market reforms. Our results also reveal that the positive association between unemployment and reforms' approval is statistically significant only for reforms that decrease existing levels of regulation. Disaggregating the results between developed and developing economies 
also reveals the different role played by institutional and political variables in affecting reform activism (e.g. political orientation of the government in power, year of election). Turning to the analysis of the short-term effects of reforms, the baseline specification shows that neither increasing nor decreasing labour market regulation has an effect on unemployment rates in the short run. However, when examining the effects of reforms at different points of the business cycle, the results confirm the hypothesis that deregulatory labour market interventions have a negative short-term effect when implemented in times of crisis, a finding that holds for the total sample of countries and for developed economies.

\section{Endnotes}

${ }^{1}$ However, our data remains limited to English language sources, and we might have therefore excluded a non-random set of interventions.

${ }^{2}$ See Appendix 2 for the definition of these variables. The only dimension of the IZA-fRDB database that we are not able to replicate is the dichotomy between incremental and discrete reforms. In the IZA-fRDB database, this is classified as to whether any policy intervention generates a change in the legislation below/above one tenth of the standard deviation of the cross-country deviation in the strictness of the relevant indicator. Due to the extensive country coverage and the inclusion of different policy domains for which indicators are not consistently available, this would be unfeasible in the present research context.

${ }^{3}$ These measures include (i) definitional validity; (ii) sufficient grade of variation; (iii) reproducibility; (iv) transparency; (v) evaluator bias; and (vi) information bias (Kucera 2007).

${ }^{4} \mathrm{~A}$ more detailed description of the trends from the policy compendium is available in Adascalitei et al. (2015).

${ }^{5}$ Following Duval (2008), this represents a better strategy than simply including in the equation the value of the government net fiscal balance. Indeed, large fiscal consolidation measures are supposed to have a disproportionately higher impact on the probability to undertake structural reforms-compared to marginal adjustment in the fiscal balance. The fiscal consolidation dummy takes the value of 1 if the country has experienced a change in the fiscal balance larger than +0.9 percentage points of GDP.

${ }^{6}$ Regional dummies correspond to the following regions (ILO classification): Developed Economies and the EU, Central and South-Eastern Europe and the CIS, East Asia, South Asia, South-East Asia and the Pacific, Latin America and the Caribbean, North Africa and the Middle East and Sub-Saharan Africa. See Appendix 2 for the list of countries covered in the present analysis by region.

${ }^{7}$ The inclusion of both the indicator of stringency of EPL and the different measures of (de)regulation (from the compendium) is meant to capture both the impact of the stringency of EPL on unemployment and the effects of deviations from this level.

${ }^{8}$ The coefficient is actually negative for the 10th and 20th percentiles of the gap growth variable for developing countries. 


\section{Appendix 1: Additional estimation results}

Table 7 Determinants of the total number of labour market reforms in developed economies

\begin{tabular}{|c|c|c|c|c|c|c|c|c|c|c|c|c|c|c|}
\hline & \multicolumn{2}{|c|}{ Total reforms } & \multicolumn{4}{|l|}{ Direction } & \multicolumn{4}{|c|}{ Temporal horizon } & \multicolumn{4}{|l|}{ Coverage } \\
\hline & \multirow[b]{2}{*}{ NBREG } & \multirow[b]{2}{*}{ OLS } & \multicolumn{2}{|c|}{ Increasing reforms } & \multicolumn{2}{|c|}{ Decreasing reforms } & \multicolumn{2}{|c|}{ Temporary reforms } & \multicolumn{2}{|c|}{ Permanent reforms } & \multicolumn{2}{|c|}{ Complete reforms } & \multicolumn{2}{|c|}{ Two-tier reforms } \\
\hline & & & NBREG & OLS & NBREG & OLS & NBREG & OLS & NBREG & OLS & NBREG & OLS & NBREG & OLS \\
\hline \multirow[t]{2}{*}{ Unemployment (lag) } & $0.052^{*}$ & 0.161 & -0.023 & -0.020 & $0.090^{* * *}$ & $0.181^{*}$ & $0.169^{* * *}$ & $0.052^{* *}$ & 0.034 & 0.109 & $0.075^{* * *}$ & 0.135 & 0.019 & 0.026 \\
\hline & $(0.027)$ & $(0.115)$ & $(0.030)$ & $(0.022)$ & $(0.032)$ & $(0.097)$ & $(0.035)$ & $(0.022)$ & $(0.027)$ & $(0.096)$ & $(0.029)$ & $(0.082)$ & $(0.032)$ & $(0.037)$ \\
\hline \multirow[t]{2}{*}{ Unemployment (difference) } & $0.130^{* *}$ & $0.419^{*}$ & 0.011 & 0.012 & $0.157^{* *}$ & $0.407^{* *}$ & $0.197^{*}$ & $0.076^{*}$ & $0.122^{*}$ & $0.342^{*}$ & $0.187^{* *}$ & $0.285^{* *}$ & 0.085 & 0.134 \\
\hline & $(0.063)$ & $(0.206)$ & $(0.079)$ & $(0.064)$ & $(0.071)$ & $(0.170)$ & $(0.110)$ & $(0.041)$ & $(0.065)$ & $(0.182)$ & $(0.073)$ & $(0.129)$ & $(0.070)$ & $(0.093)$ \\
\hline \multirow[t]{2}{*}{ Gap growth (lag) } & 0.002 & 0.067 & -0.038 & -0.025 & 0.024 & 0.091 & 0.075 & 0.020 & -0.003 & 0.047 & 0.010 & 0.045 & 0.001 & 0.022 \\
\hline & $(0.045)$ & $(0.128)$ & $(0.045)$ & $(0.035)$ & $(0.052)$ & $(0.100)$ & $(0.090)$ & $(0.014)$ & $(0.047)$ & $(0.124)$ & $(0.059)$ & $(0.098)$ & $(0.044)$ & $(0.041)$ \\
\hline \multirow[t]{2}{*}{ Fiscal consolidation } & 0.100 & 0.178 & 0.225 & 0.194 & 0.095 & -0.016 & -0.033 & -0.002 & 0.084 & 0.180 & 0.103 & 0.007 & 0.128 & 0.171 \\
\hline & $(0.206)$ & $(0.666)$ & $(0.240)$ & $(0.205)$ & $(0.237)$ & $(0.557)$ & $(0.354)$ & $(0.089)$ & $(0.225)$ & $(0.629)$ & $(0.236)$ & $(0.460)$ & $(0.202)$ & $(0.237)$ \\
\hline \multirow[t]{2}{*}{ Fixed exchange } & $0.441^{*}$ & 0.524 & $0.526^{* *}$ & $0.368^{* * *}$ & 0.521 & 0.156 & -0.006 & -0.034 & $0.491^{*}$ & 0.558 & 0.188 & 0.138 & $0.779^{* * *}$ & $0.385^{* *}$ \\
\hline & $(0.252)$ & $(0.447)$ & $(0.207)$ & $(0.118)$ & $(0.366)$ & $(0.390)$ & $(0.469)$ & $(0.070)$ & $(0.264)$ & $(0.410)$ & $(0.278)$ & $(0.305)$ & $(0.274)$ & $(0.179)$ \\
\hline \multirow[t]{2}{*}{ Election year } & -0.045 & -0.164 & 0.295 & 0.154 & -0.390 & -0.319 & -0.561 & -0.054 & -0.053 & -0.110 & -0.076 & -0.142 & -0.019 & -0.022 \\
\hline & $(0.200)$ & $(0.417)$ & $(0.259)$ & $(0.178)$ & $(0.248)$ & $(0.314)$ & $(0.590)$ & $(0.088)$ & $(0.217)$ & $(0.389)$ & $(0.245)$ & $(0.290)$ & $(0.251)$ & $(0.176)$ \\
\hline \multirow[t]{2}{*}{ Post-election } & 0.111 & 0.278 & 0.288 & 0.212 & -0.038 & 0.066 & -0.471 & -0.047 & 0.148 & 0.325 & -0.103 & 0.168 & 0.273 & 0.110 \\
\hline & $(0.203)$ & $(0.497)$ & $(0.234)$ & $(0.173)$ & $(0.273)$ & $(0.390)$ & $(0.387)$ & $(0.067)$ & $(0.231)$ & $(0.494)$ & $(0.305)$ & $(0.388)$ & $(0.208)$ & $(0.177)$ \\
\hline \multirow[t]{2}{*}{ Ideology } & $0.435^{* *}$ & 0.429 & 0.324 & 0.203 & $0.430^{*}$ & 0.225 & 0.240 & 0.056 & $0.468^{* *}$ & 0.372 & $0.538^{* *}$ & 0.355 & 0.265 & 0.073 \\
\hline & $(0.182)$ & $(0.414)$ & $(0.246)$ & $(0.171)$ & $(0.245)$ & $(0.299)$ & $(0.392)$ & $(0.078)$ & $(0.196)$ & $(0.387)$ & $(0.210)$ & $(0.291)$ & $(0.229)$ & $(0.169)$ \\
\hline \multirow[t]{2}{*}{ GDP per capita (log, 2007) } & $-0.721^{* * *}$ & -0.735 & $-0.487^{* *}$ & $-0.330^{* *}$ & $-0.984^{* * *}$ & -0.405 & 0.261 & 0.137 & $-0.820^{* * *}$ & -0.872 & $-0.712^{* *}$ & -0.361 & $-0.749^{* * *}$ & $-0.374^{*}$ \\
\hline & $(0.261)$ & $(0.619)$ & $(0.208)$ & $(0.124)$ & $(0.363)$ & $(0.531)$ & $(0.440)$ & $(0.101)$ & $(0.274)$ & $(0.545)$ & $(0.330)$ & $(0.444)$ & $(0.265)$ & $(0.217)$ \\
\hline Year dummies & Yes & Yes & Yes & Yes & Yes & Yes & Yes & Yes & Yes & Yes & Yes & Yes & Yes & Yes \\
\hline Regional dummies & Yes & Yes & Yes & Yes & Yes & Yes & Yes & Yes & No & No & Yes & Yes & Yes & Yes \\
\hline Country dummies & No & No & No & No & No & No & No & No & Yes & Yes & No & No & No & No \\
\hline (Pseudo) $R$-squared & 0.0910 & 0.2111 & 0.0827 & 0.1460 & 0.1134 & 0.2190 & 0.2025 & 0.2219 & 0.0847 & 0.1905 & 0.0926 & 0.1936 & 0.1104 & 0.1748 \\
\hline N & 245 & 245 & 245 & 245 & 245 & 245 & 245 & 245 & 245 & 245 & 245 & 245 & 245 & 245 \\
\hline
\end{tabular}

Note: Dependent variable is the total number of reforms. Standard errors in parenthesis are clustered at the country level

$* / * * * * * *$ significant at the 10,5 and 1 per cent 
Table 8 Determinants of labour reforms by policy domain in developed economies

\begin{tabular}{|c|c|c|c|c|c|c|c|c|c|c|c|c|}
\hline & \multicolumn{2}{|c|}{ Collective bargaining } & \multicolumn{2}{|c|}{ Collective dismissals } & \multicolumn{2}{|c|}{ Permanent contracts } & \multicolumn{2}{|c|}{ Temporary contracts } & \multicolumn{2}{|c|}{ Other forms of employment } & \multicolumn{2}{|c|}{ Working hours } \\
\hline & NBREG & OLS & NBREG & OLS & NBREG & OLS & NBREG & OLS & NBREG & OLS & NBREG & OLS \\
\hline \multirow[t]{2}{*}{ Unemployment (lag) } & $0.060^{* *}$ & $0.047^{* *}$ & $0.118^{* *}$ & 0.037 & 0.048 & 0.040 & 0.059 & 0.012 & -0.020 & -0.004 & $0.064^{*}$ & 0.030 \\
\hline & $(0.028)$ & $(0.020)$ & $(0.051)$ & $(0.031)$ & $(0.037)$ & $(0.041)$ & $(0.039)$ & $(0.012)$ & $(0.038)$ & $(0.010)$ & $(0.035)$ & $(0.019)$ \\
\hline \multirow[t]{2}{*}{ Unemployment (difference) } & $0.255^{* * *}$ & $0.163^{* * *}$ & 0.080 & 0.038 & 0.053 & 0.064 & 0.168 & 0.078 & 0.036 & 0.014 & 0.093 & 0.061 \\
\hline & $(0.064)$ & $(0.054)$ & $(0.114)$ & $(0.043)$ & $(0.091)$ & $(0.072)$ & $(0.135)$ & $(0.061)$ & $(0.086)$ & $(0.023)$ & $(0.086)$ & $(0.047)$ \\
\hline \multirow[t]{2}{*}{ Gap growth (lag) } & 0.063 & 0.030 & -0.098 & -0.017 & -0.015 & 0.019 & -0.094 & -0.008 & 0.059 & 0.023 & 0.048 & 0.019 \\
\hline & $(0.072)$ & $(0.031)$ & $(0.109)$ & $(0.025)$ & $(0.056)$ & $(0.052)$ & $(0.062)$ & $(0.022)$ & $(0.072)$ & $(0.025)$ & $(0.085)$ & $(0.024)$ \\
\hline \multirow[t]{2}{*}{ Fiscal consolidation } & 0.095 & 0.008 & -0.120 & -0.061 & 0.144 & 0.091 & -0.273 & -0.039 & 0.295 & 0.104 & 0.144 & 0.075 \\
\hline & $(0.294)$ & $(0.174)$ & $(0.379)$ & $(0.156)$ & $(0.288)$ & $(0.263)$ & $(0.510)$ & $(0.151)$ & $(0.319)$ & $(0.107)$ & $(0.290)$ & $(0.125)$ \\
\hline \multirow[t]{2}{*}{ Fixed exchange } & 0.189 & 0.013 & 0.599 & 0.024 & 0.278 & 0.097 & $0.778^{*}$ & 0.137 & $0.798^{* *}$ & $0.170^{* *}$ & 0.401 & 0.082 \\
\hline & $(0.310)$ & $(0.101)$ & $(0.532)$ & $(0.076)$ & $(0.355)$ & $(0.190)$ & $(0.399)$ & $(0.107)$ & $(0.356)$ & $(0.077)$ & $(0.355)$ & $(0.096)$ \\
\hline \multirow[t]{2}{*}{ Election year } & 0.017 & 0.042 & $-0.911^{*}$ & -0.038 & -0.033 & -0.054 & -0.054 & -0.040 & 0.142 & 0.018 & -0.371 & -0.092 \\
\hline & $(0.418)$ & $(0.122)$ & $(0.507)$ & $(0.076)$ & $(0.257)$ & $(0.143)$ & $(0.354)$ & $(0.089)$ & $(0.343)$ & $(0.089)$ & $(0.396)$ & $(0.097)$ \\
\hline \multirow[t]{2}{*}{ Post-election } & 0.454 & 0.198 & $0.611^{*}$ & 0.154 & -0.116 & 0.005 & -0.145 & -0.128 & 0.084 & 0.029 & -0.016 & 0.020 \\
\hline & $(0.295)$ & $(0.131)$ & $(0.333)$ & $(0.095)$ & $(0.324)$ & $(0.192)$ & $(0.579)$ & $(0.153)$ & $(0.333)$ & $(0.093)$ & $(0.337)$ & $(0.114)$ \\
\hline \multirow[t]{2}{*}{ Ideology } & 0.106 & 0.006 & -0.383 & -0.068 & 0.432 & 0.136 & 0.418 & 0.031 & $0.739^{* *}$ & 0.150 & $0.656^{*}$ & 0.174 \\
\hline & $(0.315)$ & $(0.111)$ & $(0.403)$ & $(0.068)$ & $(0.294)$ & $(0.151)$ & $(0.325)$ & $(0.069)$ & $(0.343)$ & $(0.092)$ & $(0.337)$ & $(0.118)$ \\
\hline \multirow[t]{2}{*}{ GDP per capita (log, 2007) } & $-0.762^{* *}$ & -0.100 & -0.453 & -0.004 & -0.521 & -0.232 & $-0.857^{* *}$ & -0.111 & $-1.122^{* * *}$ & $-0.191^{* * *}$ & $-0.604^{*}$ & -0.097 \\
\hline & $(0.328)$ & $(0.128)$ & $(0.735)$ & $(0.200)$ & $(0.343)$ & $(0.196)$ & $(0.425)$ & $(0.104)$ & $(0.369)$ & $(0.062)$ & $(0.355)$ & $(0.109)$ \\
\hline Year dummies & Yes & Yes & Yes & Yes & Yes & Yes & Yes & Yes & Yes & Yes & Yes & Yes \\
\hline Country dummies & No & No & No & No & No & No & No & No & No & No & No & No \\
\hline Regional dummies & Yes & Yes & Yes & Yes & Yes & Yes & Yes & Yes & Yes & Yes & Yes & Yes \\
\hline (Pseudo) $R$-squared & 0.1183 & 0.1948 & 0.1830 & 0.1307 & 0.0736 & 0.1194 & 0.1056 & 0.0715 & 0.1715 & 0.1456 & 0.0997 & 0.1416 \\
\hline N & 245 & 245 & 245 & 245 & 245 & 245 & 245 & 245 & 245 & 245 & 245 & 245 \\
\hline
\end{tabular}

Note: Dependent variable is the total number of reforms for each category identified. Standard errors in parenthesis are clustered at the country leve

$* * * * * *$ significant at the 10,5 and 1 per cent 
Table 9 Determinants of the total number of labour market reforms in developing economies

\begin{tabular}{|c|c|c|c|c|c|c|c|c|c|c|c|c|c|c|}
\hline & \multicolumn{2}{|c|}{ Total reforms } & \multicolumn{4}{|l|}{ Direction } & \multicolumn{4}{|c|}{ Temporal horizon } & \multicolumn{4}{|c|}{ Coverage } \\
\hline & \multirow[b]{2}{*}{ NBREG } & \multirow[b]{2}{*}{ OLS } & \multicolumn{2}{|c|}{ Increasing reforms } & \multicolumn{2}{|c|}{ Decreasing reforms } & \multicolumn{2}{|c|}{ Temporary reforms } & \multicolumn{2}{|c|}{ Permanent reforms } & \multicolumn{2}{|c|}{ Complete reforms } & \multicolumn{2}{|c|}{ Two-tier reforms } \\
\hline & & & NBREG & OLS & NBREG & OLS & NBREG & OLS & NBREG & OLS & NBREG & OLS & NBREG & OLS \\
\hline \multirow[t]{2}{*}{ Unemployment (lag) } & 0.006 & 0.003 & 0.009 & 0.002 & 0.008 & 0.001 & $0.147^{* *}$ & $0.003^{* *}$ & -0.002 & 0.001 & 0.014 & 0.006 & -0.036 & -0.002 \\
\hline & $(0.013)$ & $(0.007)$ & $(0.017)$ & $(0.006)$ & $(0.020)$ & $(0.004)$ & $(0.064)$ & $(0.001)$ & $(0.013)$ & $(0.006)$ & $(0.015)$ & $(0.007)$ & $(0.036)$ & $(0.002)$ \\
\hline \multirow[t]{2}{*}{ Unemployment (difference) } & -0.146 & -0.057 & -0.091 & -0.029 & -0.201 & -0.028 & -0.746 & -0.007 & -0.144 & -0.050 & -0.114 & -0.045 & -0.143 & $-0.011^{*}$ \\
\hline & $(0.125)$ & $(0.049)$ & $(0.098)$ & $(0.036)$ & $(0.175)$ & $(0.019)$ & $(0.509)$ & $(0.009)$ & $(0.118)$ & $(0.044)$ & $(0.107)$ & $(0.046)$ & $(0.100)$ & $(0.007)$ \\
\hline \multirow[t]{2}{*}{ Gap growth (lag) } & 0.041 & 0.011 & 0.048 & 0.009 & 0.027 & 0.001 & 0.105 & 0.001 & 0.041 & 0.009 & 0.021 & 0.004 & $0.145^{* *}$ & $0.007^{*}$ \\
\hline & $(0.032)$ & $(0.010)$ & $(0.032)$ & $(0.007)$ & $(0.053)$ & $(0.008)$ & $(0.099)$ & $(0.002)$ & $(0.032)$ & $(0.010)$ & $(0.033)$ & $(0.009)$ & $(0.065)$ & $(0.004)$ \\
\hline \multirow[t]{2}{*}{ Fiscal consolidation } & 0.110 & 0.042 & 0.088 & 0.020 & 0.204 & 0.022 & 0.237 & -0.004 & 0.142 & 0.046 & 0.049 & 0.012 & 0.440 & 0.030 \\
\hline & $(0.198)$ & $(0.078)$ & $(0.189)$ & $(0.055)$ & $(0.420)$ & $(0.053)$ & $(0.707)$ & $(0.019)$ & $(0.215)$ & $(0.080)$ & $(0.208)$ & $(0.068)$ & $(0.362)$ & $(0.027)$ \\
\hline \multirow[t]{2}{*}{ Fixed exchange } & 0.012 & -0.014 & -0.439 & -0.091 & $1.003^{*}$ & 0.077 & $2.178^{* *}$ & $0.087^{* *}$ & -0.323 & -0.101 & 0.173 & 0.038 & $-14.291^{* * *}$ & $-0.052^{*}$ \\
\hline & $(0.215)$ & $(0.076)$ & $(0.393)$ & $(0.064)$ & $(0.544)$ & $(0.070)$ & $(0.958)$ & $(0.036)$ & $(0.239)$ & $(0.066)$ & $(0.214)$ & $(0.072)$ & $(0.794)$ & $(0.027)$ \\
\hline \multirow[t]{2}{*}{ Election year } & -0.016 & -0.003 & -0.230 & -0.061 & $0.604^{*}$ & 0.058 & 0.697 & 0.014 & -0.040 & -0.017 & -0.084 & -0.024 & 0.294 & 0.021 \\
\hline & $(0.214)$ & $(0.088)$ & $(0.267)$ & $(0.072)$ & $(0.345)$ & $(0.051)$ & $(0.964)$ & $(0.021)$ & $(0.229)$ & $(0.087)$ & $(0.226)$ & $(0.075)$ & $(0.443)$ & $(0.036)$ \\
\hline \multirow[t]{2}{*}{ Post-election } & $-0.396^{*}$ & $-0.127^{*}$ & $-0.550^{* *}$ & $-0.131^{* *}$ & -0.093 & 0.004 & 1.075 & 0.028 & $-0.507^{* *}$ & $-0.155^{* *}$ & -0.363 & -0.100 & -0.586 & -0.027 \\
\hline & $(0.224)$ & $(0.075)$ & $(0.251)$ & $(0.055)$ & $(0.360)$ & $(0.046)$ & $(0.797)$ & $(0.022)$ & $(0.241)$ & $(0.073)$ & $(0.246)$ & $(0.071)$ & $(0.580)$ & $(0.026)$ \\
\hline \multirow[t]{2}{*}{ Ideology } & 0.181 & 0.076 & $0.377^{*}$ & 0.106 & -0.307 & -0.030 & -0.935 & -0.015 & 0.215 & 0.090 & 0.336 & 0.115 & -0.802 & -0.039 \\
\hline & $(0.211)$ & $(0.092)$ & $(0.210)$ & $(0.066)$ & $(0.407)$ & $(0.042)$ & $(0.841)$ & $(0.012)$ & $(0.222)$ & $(0.093)$ & $(0.213)$ & $(0.081)$ & $(0.646)$ & $(0.027)$ \\
\hline \multirow[t]{2}{*}{ GDP per capita (log, 2007) } & $0.173^{* *}$ & 0.054 & 0.122 & 0.024 & $0.295^{* *}$ & 0.030 & 0.166 & -0.001 & $0.178^{* *}$ & 0.054 & 0.153 & 0.041 & 0.195 & 0.012 \\
\hline & $(0.079)$ & $(0.033)$ & $(0.115)$ & $(0.031)$ & $(0.149)$ & $(0.023)$ & $(0.367)$ & $(0.007)$ & $(0.083)$ & $(0.034)$ & $(0.097)$ & $(0.033)$ & $(0.176)$ & $(0.013)$ \\
\hline Year dummies & Yes & Yes & Yes & Yes & Yes & Yes & Yes & Yes & Yes & Yes & Yes & Yes & Yes & Yes \\
\hline Regional dummies & Yes & Yes & Yes & Yes & Yes & Yes & Yes & Yes & No & No & Yes & Yes & Yes & Yes \\
\hline Country dummies & No & No & No & No & No & No & No & No & Yes & Yes & No & No & No & No \\
\hline (Pseudo) R-squared & 0.0373 & 0.0579 & 0.0393 & 0.0489 & 0.0801 & 0.0574 & 0.3468 & 0.0706 & 0.0375 & 0.0555 & 0.0439 & 0.0617 & 0.0987 & 0.0416 \\
\hline N & 420 & 420 & 420 & 420 & 420 & 420 & 420 & 420 & 420 & 420 & 420 & 420 & 420 & 420 \\
\hline
\end{tabular}

Note: Dependent variable is the total number of reforms. Standard errors in parenthesis are clustered at the country level

$* / * * * * *$ significant at the 10,5 and 1 per cent 
Table 10 Determinants of labour reforms by policy domain in developing economies

\begin{tabular}{|c|c|c|c|c|c|c|c|c|c|c|c|c|}
\hline & \multicolumn{2}{|c|}{ Collective bargaining } & \multicolumn{2}{|c|}{ Collective dismissals } & \multicolumn{2}{|c|}{ Permanent contracts } & \multicolumn{2}{|c|}{ Temporary contracts } & \multicolumn{2}{|c|}{ Other forms of employment } & \multicolumn{2}{|c|}{ Working hours } \\
\hline & NBREG & OLS & NBREG & OLS & NBREG & OLS & NBREG & OLS & NBREG & OLS & NBREG & OLS \\
\hline \multirow[t]{2}{*}{ Unemployment (lag) } & 0.011 & 0.001 & $0.084^{* *}$ & 0.003 & -0.010 & -0.001 & 0.014 & 0.002 & -0.153 & -0.002 & -0.004 & -0.000 \\
\hline & $(0.018)$ & $(0.003)$ & $(0.033)$ & $(0.002)$ & $(0.022)$ & $(0.003)$ & $(0.027)$ & $(0.002)$ & $(0.102)$ & $(0.001)$ & $(0.060)$ & $(0.001)$ \\
\hline \multirow[t]{2}{*}{ Unemployment (difference) } & -0.018 & -0.002 & 0.010 & -0.011 & -0.126 & -0.014 & $-0.241^{* *}$ & -0.025 & $-0.190^{*}$ & -0.002 & -0.037 & -0.002 \\
\hline & $(0.121)$ & $(0.021)$ & $(0.067)$ & $(0.009)$ & $(0.102)$ & $(0.015)$ & $(0.108)$ & $(0.016)$ & $(0.098)$ & $(0.002)$ & $(0.128)$ & $(0.003)$ \\
\hline \multirow[t]{2}{*}{ Gap growth (lag) } & 0.008 & 0.002 & 0.250 & 0.003 & 0.064 & 0.004 & 0.001 & -0.000 & -0.016 & -0.000 & 0.155 & 0.002 \\
\hline & $(0.038)$ & $(0.006)$ & $(0.158)$ & $(0.002)$ & $(0.056)$ & $(0.005)$ & $(0.065)$ & $(0.003)$ & $(0.029)$ & $(0.001)$ & $(0.127)$ & $(0.001)$ \\
\hline \multirow[t]{2}{*}{ Fiscal consolidation } & 0.002 & 0.003 & 0.636 & 0.008 & 0.159 & 0.003 & 0.311 & 0.008 & -0.516 & -0.002 & 1.332 & 0.021 \\
\hline & $(0.269)$ & $(0.053)$ & $(0.780)$ & $(0.017)$ & $(0.349)$ & $(0.037)$ & $(0.510)$ & $(0.023)$ & $(0.973)$ & $(0.013)$ & $(1.005)$ & $(0.021)$ \\
\hline \multirow[t]{2}{*}{ Fixed exchange } & 0.590 & 0.116 & $-14.847^{* * *}$ & -0.001 & -0.804 & -0.080 & $-14.443^{* * *}$ & $-0.038^{*}$ & $-16.855^{* * *}$ & -0.013 & $-14.449^{* * *}$ & 0.002 \\
\hline & $(0.406)$ & $(0.104)$ & $(1.417)$ & $(0.012)$ & $(0.944)$ & $(0.062)$ & $(0.801)$ & $(0.022)$ & $(1.001)$ & $(0.011)$ & $(1.736)$ & $(0.004)$ \\
\hline \multirow[t]{2}{*}{ Election year } & -0.346 & -0.065 & 0.369 & 0.012 & -0.307 & -0.025 & $1.100^{* *}$ & $0.068^{*}$ & 0.035 & -0.002 & 0.652 & 0.008 \\
\hline & $(0.305)$ & $(0.053)$ & $(0.608)$ & $(0.016)$ & $(0.412)$ & $(0.042)$ & $(0.474)$ & $(0.037)$ & $(1.104)$ & $(0.016)$ & $(1.068)$ & $(0.017)$ \\
\hline \multirow[t]{2}{*}{ Post-election } & -0.413 & -0.070 & 0.126 & 0.011 & $-0.834^{* *}$ & $-0.067^{*}$ & -0.031 & 0.003 & -0.429 & -0.005 & 0.655 & 0.002 \\
\hline & $(0.278)$ & $(0.048)$ & $(0.649)$ & $(0.018)$ & $(0.413)$ & $(0.034)$ & $(0.665)$ & $(0.025)$ & $(1.103)$ & $(0.014)$ & $(1.152)$ & $(0.016)$ \\
\hline \multirow[t]{2}{*}{ Ideology } & 0.359 & 0.072 & -0.014 & 0.004 & 0.051 & 0.007 & -0.027 & -0.001 & -0.417 & -0.001 & -0.101 & -0.005 \\
\hline & $(0.308)$ & $(0.072)$ & $(0.621)$ & $(0.020)$ & $(0.376)$ & $(0.047)$ & $(0.432)$ & $(0.023)$ & $(0.912)$ & $(0.007)$ & $(1.034)$ & $(0.011)$ \\
\hline \multirow[t]{2}{*}{ GDP per capita (log, 2007) } & -0.035 & -0.008 & 0.179 & 0.006 & 0.210 & 0.016 & $0.364^{*}$ & $0.017^{*}$ & 0.476 & 0.008 & $0.795^{* *}$ & $0.014^{*}$ \\
\hline & $(0.121)$ & $(0.020)$ & $(0.316)$ & $(0.008)$ & $(0.171)$ & $(0.021)$ & $(0.190)$ & $(0.010)$ & $(0.639)$ & $(0.012)$ & $(0.315)$ & $(0.007)$ \\
\hline Year dummies & Yes & Yes & Yes & Yes & Yes & Yes & Yes & Yes & Yes & Yes & Yes & Yes \\
\hline Country dummies & No & No & No & No & No & No & No & No & No & No & No & No \\
\hline Regional dummies & Yes & Yes & Yes & Yes & Yes & Yes & Yes & Yes & Yes & Yes & Yes & Yes \\
\hline (Pseudo) $R$-squared & 0.0440 & 0.0447 & 0.2727 & 0.0654 & 0.1105 & 0.0595 & 0.1346 & 0.0582 & 0.2327 & 0.0252 & 0.3033 & 0.0462 \\
\hline N & 420 & 420 & 420 & 420 & 420 & 420 & 420 & 420 & 420 & 420 & 420 & 420 \\
\hline
\end{tabular}

Note: Dependent variable is the total number of reforms for each category identified. Standard errors in parenthesis are clustered at the country leve

******* significant at the 10,5 and 1 per cent 


\section{Appendix 2}

\subsection{Description of variables}

\subsubsection{Total reforms}

Total reforms are the number of changes to the labour market legislation passed in each country annually. In the paper, this is further differentiated according to the following policy subdomains: (i) collective bargaining; (ii) collective dismissals; (iii) permanent contracts; (iv) temporary contracts; (v) working hours; and (vi) other forms of employment.

Source: Authors' calculations based on the ILO EPLex and NATLEX databases, EU Commission LABREF and fRDB-IZA database of social reforms

\subsubsection{Reforms increasing/decreasing the legislation}

For the purpose of the analysis (i) for permanent contracts, temporary contracts, collective dismissals and other forms of employment, reforms that increase (decrease) regulation are considered as those that make firing procedures more (less) expensive and/or more (less) procedurally complex; (ii) for collective bargaining, an increase (decrease) in labour legislation is considered if the legislation promotes a centralization (decentralization) of collective bargaining; (iii) for working hours, a reform increases (decreases) labour legislation if it limits (facilitates) employers' ability to set and modify working hours unilaterally.

Source: Authors' calculations based on the ILO EPLex and NATLEX databases, EU Commission LABREF and fRDB-IZA database of social reforms

\subsubsection{Reforms of permanent/temporary nature}

Permanent reforms are those introducing long-term/indefinite changes in the labour law. Temporary reforms are changes that have a pre-established limited temporal duration.

Source: Authors' calculations based on ILO EPLex and NATLEX databases, EU Commission LABREF and fRDB-IZA database of social reforms

\subsubsection{Complete and two-tier reforms}

Two-tier measures are those involving only a fraction of the potentially eligible population (i.e. below the majority). Complete measures are instead those affecting the majority of the potentially eligible population.

Source: Authors' calculations based on ILO EPLex and NATLEX databases, EU Commission LABREF and fRDB-IZA database of social reforms

\subsubsection{Reform stance}

Reform stance is the number of reforms that decrease labour market regulation net of the number of reforms that increase it. It is computed in each specific year and country, irrespective of the policy domains or characteristics of the reform.

Source: Authors' calculations based on the ILO EPLex and NATLEX databases, EU Commission LABREF and fRDB-IZA database of social reforms

\subsubsection{Gap growth}

Gap growth is the difference between GDP growth at time $t$ and the 5-year moving average centred on time $t$.

Source: Authors' calculations based on the IMF World Economic Outlook database 


\subsubsection{Fiscal consolidation}

Fiscal consolidation is the dummy variable which-following Duval (2008) - takes the value of 1 if the country has experienced a change in the fiscal balance larger than +0.9 percentage points of GDP.

Source: Authors' calculations based on the IMF World Economic Outlook database

\subsubsection{Fixed exchange}

Fixed exchange is the dummy variable taking the value of 1 if the country has a fixed exchange regime (exchange arrangement with no separate legal tender or currency board) or alternatively is part of a monetary union.

Source: IMF Annual Report on Exchange Rate Arrangements

\subsubsection{Ideology}

Ideology is the dummy taking the value of 1 if the country has a left-wing government in power.

Source: World Bank Database of Political Institution

\subsubsection{Election and post-election years}

Election and post-election years are the dummies taking the value of 1 if the country has had a legislative election in the current or previous year, respectively.

Source: World Bank Database of Political Institution

\subsubsection{Tax rate}

Tax rate is the top marginal income tax rate (standardized between 0 and 100).

Source: Economic Freedom of the World Dataset

\subsubsection{EPL indicator}

EPL indicator is the inverse of the indicator of labour market freedom (standardized between 0 and 100).

Source: Economic Freedom of the World Dataset

\subsection{List of countries included in the analysis by region}

\subsubsection{Developed Economies and the EU}

This is composed of the following: Australia, Austria, Belgium, Bulgaria, Canada, Croatia, Cyprus, Czech Republic, Denmark, Estonia, Finland, France, Germany, Greece, Hungary, Ireland, Israel, Italy, Japan, Latvia, Lithuania, Luxembourg, Malta, Netherlands, New Zealand, Norway, Poland, Portugal, Romania, San Marino, Slovakia, Slovenia, Spain, Sweden, Switzerland, UK and USA.

\subsubsection{Central and South-Eastern Europe and the CIS}

This is composed of the following: Albania, Armenia, Azerbaijan, Belarus, Georgia, Kyrgyzstan, Macedonia, Montenegro, Republic of Moldova, Russian Federation, Serbia, Tajikistan, Turkey and Ukraine.

\subsubsection{South Asia}

This is composed of the following: Afghanistan, Bangladesh, India, Maldives and Pakistan.

\subsubsection{South-East Asia and the Pacific}

This is composed of the following: Cambodia, Indonesia, Lao People's Democratic Republic, Malaysia, Philippines, Thailand, Viet Nam, Fiji and Kiribati.

\subsubsection{East Asia}

This is composed of the following: China, Hong Kong and Korea. 


\subsubsection{Latin America and the Caribbean}

This is composed of the following: Antigua and Barbuda, Argentina, Barbados, Bolivia, Brazil, Colombia, Costa Rica, El Salvador, Grenada, Jamaica, Mexico, Panama, Peru, Uruguay and Venezuela.

\subsubsection{North Africa and the Middle East}

This is composed of the following: Egypt, Iran, Jordan, Morocco, Sudan and United Arab Emirates.

\subsubsection{Sub-Saharan Africa}

This is composed of the following: Angola, Burkina Faso, Cameroon, Cape Verde, Central African Republic, Congo, Djibouti, Ethiopia, Gabon, Guinea, Madagascar, Malawi, Mauritius, Mozambique, Rwanda, Senegal, South Africa, Swaziland, Uganda, Zambia and Zimbabwe.

\section{Competing interests}

The IZA Journal of Labor Policy is committed to the IZA Guiding Principles of Research Integrity. The authors declare that they have observed these principles.

\section{Acknowledgements}

The authors would like to thank Santo Milasi and Steven Tobin (ILO), seminar participants in Pisa (Scuola Superiore Sant'Anna, April 2016), Geneva (ILO-IZA Conference, March 2016) and Gijon (XVII World Economy Meeting, June 2015), the editor and an anonymous referee for useful comments and suggestions. Verónica Escudero, Richard Horne, Elva López Mourelo, Naren Prasad, Johanna Silvander and Raymond Torres (all ILO) provided comments on an earlier version of the paper. The opinions expressed herein are those of the authors and cannot be attributed to the International Labour Organization.

Responsible editor: Juan Jimeno

\section{Author details}

${ }^{1}$ Central European University, Nador Street 9, Budapest H1051, Hungary. ${ }^{2}$ Research Department, International Labour Organization, Route des Morillons 4, Geneva CH1211, Switzerland.

Received: 15 October 2015 Accepted: 24 June 2016

Published online: 11 August 2016

\section{References}

Adascalitei D, Khatiwada S, Malo MA, Pignatti Morano C (2015) Employment protection and collective bargaining during the Great Recession: a comprehensive review of international evidence. Revista de Economia Laboral 12:50-87

Avdagic S, Salardi P (2013) Tenuous link: labour market institutions and unemployment in advanced and new market economies. Soc Econ Rev 11:739-769

Bassanini A (2015) A bitter medicine? Short-term employment impact of deregulation in network industries, IZA Discussion Paper No. 9187

Bassanini A, Duval R (2006) The determinants of unemployment across OECD countries: reassessing the role of policies and institutions. OECD Econ Stud 42:7-86

Bean C (1998) The interaction of aggregate-demand policies and labour market reform. Swed Econ Policy Rev 5 : $353-382$

Berg J (ed) (2015) Labour markets, institutions and inequality: building just societies in the 21st century. Edward Elgar Publishing, Cheltenham

Bernal-Verdugo LE, Furceri D, Guillaume DM (2012) Crises, labor market policy, and unemployment, IMF Working Paper 12-65

Bertola G, Blau F, Kahn L (2007) Labor market institutions and demographic employment patterns. J Popul Econ 20: 833-867

Boeri T (2011) Institutional reforms and dualism in European labor markets. In: Ashenfelter O, Card D (eds) Handbook of labor economics, vol 4, 1st edn., Elsevier, North Holland, p 1173-1236

Boeri T, Garibaldi P (2007) Two tier reforms of employment protection: a honeymoon effect? Econ J 117:357-385

Boeri T, Cahuc P, Zylberberg A (2015) The costs of flexibility-enhancing structural reforms: a literature review, OECD Economics Department Working Paper No. 1264

Bollen K, Paxton P (2000) Subjective measures of liberal democracy. Comp Pol Stud 33:58-86

Bouis R, Causa O, Demmou L, Duval R (2012) How quickly does structural reform pay off? An empirical analysis of the short-term effects of unemployment benefit reform. IZA J Labor Policy 1:12

Cacciatore M, Duval R, Fiori G (2012) Short-term gain or pain? A DSGE model-based analysis of the short-term effects of structural reforms in labour and product markets, OECD Economics Department Working Papers 948

Calmfors L (2001) Unemployment, labor market reform, and monetary union. J Labor Econ 19:265-289

Campos NF, Nugent JB (2012) The dynamics of the regulation of labor in developing and developed countries since 1960, William Davidson Institute Working Paper 1037

Daveri F, Tabellini G (2000) Unemployment, growth and taxation in industrial countries. Econ Policy 15:47-104 
Duval R (2008) Is there a role for macroeconomic policy in fostering structural reforms? Panel evidence from OECD countries over the past two decades. Eur J Polit Econ 24:491-502

Duval R, Elmeskov J (2006) The effects of EMU on structural reforms in labour and product markets, ECB Working Paper 596 Eichengreen B, Wyplosz C (1998) The stability pact: more than a minor nuisance? Econ Policy 26:65-113

Elmeskov J, Marti JP, Scarpetta S (1998) Key lessons for labour market reforms: evidence from OECD countries' experience. Swed Econ Pol Rev 5:205-252

Feldmann H (2009) The unemployment effects of labor regulation around the world. J Comp Econ 37:76-90

Fernandez R, Rodrik D (1991) Resistance to reform: status quo bias in the presence of individual-specific uncertainty. Am Econ Rev 81:1146-1155

Høj J, Galasso V, Nicoletti G, Dang T-T (2006) The political economy of structural reform: Empirical Evidence from OECD Countries, OECD Economics Department Working Papers 501

ILO (2012) Employment protection and industrial relations: recent trends and labour market impacts. In: ILO (ed) World of Work Report 2012: better jobs for a better economy. International Labour Office, Geneva, pp 35-56

ILO (2015a) Labour regulation and employment patterns. In: ILO (ed) World employment and social outlook: the changing nature of jobs. International Labour Office, Geneva, pp 111-130

ILO (2015b) Emerging patterns of employment: global and regional trends. In: ILO (ed) World employment and social outlook: the changing nature of jobs. International Labour Office, Geneva, pp 17-38

IMF (2004) Fostering structural reforms in industrial countries. In: IMF (ed) World economic outlook. Advancing structural reforms. International Monetary Fund, Washington DC, pp 103-146

IMF (2015) Where are we headed? Perspectives on potential output. In: IMF (ed) World economic outlook: short- and long-term factors. International Monetary Fund, Washington DC, pp 69-110

Kucera D (2007) Measuring trade union rights by violations of these rights in D Kucera (ed) Qualitative indicators of labour standards: comparative methods and applications. Springer, Dordrecht, pp 145-82

List JA (2001) US county-level determinants of inbound FDI: evidence from a two-step modified count data model. Int $J$ Ind Organ 19:953-973

Long SJ, Freese J (2001) Regression models for categorical dependent variables using STATA. Stata Press, Texas

Nickell S, Nunziata L, Ochel W (2005) Unemployment in the OECD since the 1960s. What do we know? Econ J 115:1-27 OECD (2012) Structural reforms in times of crisis in OECD (ed) Economic Policy Reforms 2012: going for growth. Organization for economic co-operation and development, Paris, pp 17-50

Riphahn RT, Wambach A, Million A (2003) Incentive effects in the demand for health care: a bivariate panel count data estimation. J Appl Econ 18:387-405

Sanchez Puerta ML (2010) Labor market policy research for developing countries: recent examples from the literature. What do we know and what should we now? Social Protection Discussion Paper No. 1001. World Bank, Washington DC

Sertic BA, Casni AC, Vuckovic V (2015) Impact of labour market reforms on economic activity in European Union: short term costs and long term. Institute of Public Finance 39:83-107

Teitelbaum E (2010) Measuring trade union rights through violations recorded in textual sources: an assessment. Pol Res Q 63:461-474

Turrini A, Koltay G, Pierini F, Goffard C, Kiss A (2015) A decade of labour market reforms in the EU: insights from the LABREF database. IZA J Labor Policy 4:12

World Bank (2013) World Development Report 2013: jobs. World Bank, Washington DC

\section{Submit your manuscript to a SpringerOpen ${ }^{\circ}$} journal and benefit from:

- Convenient online submission

- Rigorous peer review

- Immediate publication on acceptance

- Open access: articles freely available online

- High visibility within the field

- Retaining the copyright to your article

Submit your next manuscript at $>$ springeropen.com 